( 2022 , The Authors. Published by Elsevier Inc. and Fass Inc. on behalf of the American Dairy Science Association ${ }^{\circledR}$. This is an open access article under the CC BY license (http://creativecommons.org/licenses/by/4.0/).

\title{
Symposium review: Adipose tissue endocrinology in the periparturient period of dairy cows*
}

\author{
Susanne Häussler, ${ }^{1} \dagger$ Hassan Sadri, ${ }^{2} \ddagger$ Morteza H. Ghaffari, ${ }^{1}$ and Helga Sauerwein ${ }^{1}$ \\ ${ }^{1}$ Institute of Animal Science, Physiology Unit, University of Bonn, 53115 Bonn, Germany \\ ${ }^{2}$ Department of Clinical Science, Faculty of Veterinary Medicine, University of Tabriz, 516616471 Tabriz, Iran
}

\begin{abstract}
The involvement of adipose tissue (AT) in metabolism is not limited to energy storage but turned out to be much more complex. We now know that in addition to lipid metabolism, AT is important in glucose homeostasis and AA metabolism and also has a role in inflammatory processes. With the discovery of leptin in 1994, the concept of AT being able to secrete messenger molecules collectively termed as adipokines, and acting in an endo-, para-, and autocrine manner emerged. Moreover, based on its asset of receptors, many stimuli from other tissues reaching AT via the bloodstream can also elicit distinct responses and thus integrate AT as a control element in the regulatory circuits of the whole body's functions. The protein secretome of human differentiated adipocytes was described to comprise more than 400 different proteins. However, in dairy cows, the characterization of the physiological time course of adipokines in AT during the transition from pregnancy to lactation is largely limited to the mRNA level; for the protein level, the analytical methods are limited and available assays often lack sound validation. In addition to proteinaceous adipokines, small compounds such as steroids can also be secreted from AT. Due to the lipophilic nature of steroids, they are stored in AT, but during the past years, AT became also known as being able to metabolize and even to generate steroid hormones de novo. In high-yielding dairy cows, AT is substantially mobilized due to increased energy
\end{abstract}

Received August 30, 2021.

Accepted January 5, 2022.

*Presented as part of the Animal Health Symposium: Adipose Tissue in Transition Dairy Cows as an Integrator of Metabolic and Inflammatory Cues in Health and Disease at the ADSA Annual Meeting, July 2021.

†Corresponding author: susanne.haeussler@uni-bonn.de

$\ddagger$ Current address: Department of Clinical Science, Faculty of Veterinary Medicine, University of Tabriz, 516616471 Tabriz, Iran. Hassan Sadri was a visiting scientist at the Institute of Animal Science, Physiology Unit, University of Bonn, 53115 Bonn, Germany, at the time the research was done. requirements related to lactation. As to whether the steroidogenic system in AT is affected and may change during the common loss of body fat is largely unknown. Moreover, most research about AT in transition dairy cows is based on subcutaneous AT, whereas other depots have scarcely been investigated. This contribution aims to review the changes in adipokine mRNA andwhere available - protein expression with time relative to calving in high-yielding dairy cows at different conditions, including parity, body condition, diet, specific feed supplements, and health disorders. In addition, the review provides insights into steroidogenic pathways in dairy cows AT, and addresses differences between fat depots where possible.

Key words: adipokines, adipose tissue, endocrinology, periparturient period

\section{INTRODUCTION}

Adipose tissue (AT) is not only a simple energy store, but is also considered as an endocrine organ that produces factors regulating lipid homeostasis, insulin sensitivity, glucose metabolism, fat distribution, and inflammation (Kershaw and Flier, 2004; Coelho et al., 2013). Signaling molecules produced and secreted by AT, termed adipokines, include cytokines, hormones, growth factors, chemokines, complement factors, and various other proteins. In addition to proteins, lipids, metabolites, noncoding RNAs, and extracellular vesicles are released by AT, contributing to maintaining systemic homeostasis (Funcke and Scherer, 2019). Moreover, due to their lipophilic properties, steroid hormones are stored in AT and can also be metabolized or converted to other steroids depending on the enzyme composition (Deslypere et al., 1985; DiamantiKandarakis, 2007), with significant metabolic effects in the early lactation of cows (Grummer et al., 1990; Bell, 1995). Trayhurn and Wood (2004) suggested describing the entirety of proteins and lipids as adipokinome, according to biological omics approaches. Adipokines play an important role in the communication of cells within $\mathrm{AT}$, but also in the endocrine crosstalk with other tis- 
sues such as liver and skeletal muscle (Romacho et al., 2014). In ruminants, data on adipokines mainly focus on mRNA; thus, asides from leptin and adiponectin, protein data from adipokines in AT and in the circulation are very limited.

In high-yielding dairy cows, the period around parturition is characterized by extensive physiological and metabolic adaptations: Within a short period, energy requirements increase due to the onset of lactation compared with precalving requirements (Bell, 1995; Drackley et al., 2005). Consequently, most high-yielding dairy cows experience a negative energy balance (NEB) at the onset of lactation, leading to the mobilization of body reserves mainly from AT and muscle tissues (Drackley, 1999). Lipolysis results in increased blood concentrations of free fatty acids (FFA), which can lead to metabolic diseases such as fatty liver and ketosis (Adewuyi et al., 2005). Larger initial fat depots in late lactation lead to increased mobilization of AT in the subsequent lactation, with over-conditioned cows consuming less DM due to circulating FFA and resulting ketone bodies (Rukkwamsuk et al., 1999; Laeger et al., 2013). Increased peripartum lipolysis also affects the immune system and reproduction of dairy cows; the direct effects of increased FFA and BHB concentrations on various immune cells have been demonstrated in vitro and in vivo (Bernabucci et al., 2005; Lacetera et al., 2005; Scalia et al., 2006). Furthermore, increased hepatic triglyceride storage may lead to fatty liver in early-lactating dairy cows (Trevisi et al., 2013). The excessive lipolysis in early-lactating dairy cows might originate from various AT depots, with greater lipolytic capacity from retroperitoneal AT, compared with subcutaneous AT (Kenéz et al., 2015). Moreover, depotspecific variations of AT have been observed in homeorhetic adaptations during the periparturient period in dairy cows and should be considered when regarding endocrine responses and adipose energy metabolism at the onset of lactation (Kenéz et al., 2019).

This paper reviews the changes in adipokine mRNA and, where available, protein expression over time relative to calving in high-yielding dairy cows under a variety of conditions, such as parity, body condition, diet, specific feed supplements, and health disorders. In addition, the review highlights recent findings related to steroidogenic pathways in AT from dairy cows. Moreover, differences between fat depots are addressed where possible.

\section{Adipose Tissue as an Endocrine Organ}

Being a highly active metabolic and endocrine organ, $\mathrm{AT}$ is the major energy store in the body for excess energy. However, it can also express and secrete several biologically active factors that regulate metabolic homeostasis, fat distribution, satiety, insulin sensitivity, and secretion (Rosen and Spiegelman, 2006; Coelho et al., 2013). Various adipokines, such as leptin, adiponectin, chemerin, visfatin, pigment epithelium-derived factor (PEDF), resistin, fibroblast growth factor 21 (FGF21), retinol-binding protein 4 (RBP4), apelin, omentin, and many others are produced and secreted by AT (Funcke and Scherer, 2019). In addition to these adipokines, AT produces and secretes inflammatory cytokines [e.g., tumor necrosis factor- $\alpha$ (TNF- $\alpha)$, IL6 , and monocyte chemotactic protein-1 (MCP-1); Funcke and Scherer, 2019], acute phase proteins (e.g., haptoglobin, acid glycoprotein, and serum amyloid A; Ceciliani et al., 2012), many lipids (e.g., endocannabinoids, prostaglandins, steroids, and FFA), complement and complement-related proteins, proteins of fibrinolytic, enzymes, and lipid transport (Kershaw and Flier, 2004; Ahima, 2006). Adipose-derived factors are involved in the regulation of metabolism by communicating within AT or between other organs and tissues involved in metabolic processes, such as liver, pancreas, skeletal muscle, heart, and brain (Kita et al., 2019). In humans and mice, receptors for the adipokines leptin, adiponectin, and resistin as well as for the cytokine TNF- $\alpha$ were shown to be expressed in the central nervous system (CNS; Parimisetty et al., 2016). To exert their function via receptors in the CNS, adipokines have to cross the blood-brain barrier or affect the CNS indirectly via pathways stimulated by cells of the blood-brain barrier. Being involved in feeding behavior, leptin could be synthesized de novo in the brain from rodents, acting directly on the CNS (Parimisetty et al., 2016). Lipolysis from AT depots during the transition period coincides with a period of induced AT remodeling (Contreras et al., 2017, 2018) and decreased insulin sensitivity in hepatocytes, adipocytes, and myocytes, redirecting energy toward milk synthesis (De Koster and Opsomer, 2013). Intense and prolonged lipolysis leads to changes in the secretion pattern of adipokines and is simultaneously modulated by these bioactive compounds (Bell and Bauman, 1997; Contreras et al., 2017). Bovine adipocytes become more sensitive to insulin as lactation progresses, resulting in decreased rates of lipolysis and increased lipogenesis (McNamara, 1994). Moderate insulin resistance in AT might ensure healthy and productive lactation during the transition period; however, when insulin resistance in AT is intense and prolonged, it predisposes dairy cows to inflammation and metabolic dysfunction by limiting the ability of AT to expand its energy buffering capacity (De Koster and Opsomer, 2013). 


\section{Adipokines: Definition, Structure, and Assessment}

The collective name adipokines was recommended to describe proteins that are synthesized and secreted by AT; moreover, restricting the term to those proteins that are secreted exclusively from adipocytes (and not by the stromal vascular cells present in AT) was suggested (Trayhurn and Wood, 2004). However, the term adipokine is commonly used to refer to AT-derived proteins. With growing knowledge about far more compounds being released from AT (i.e., noncoding RNA, nonlipid metabolites, and extracellular vesicles), extended definitions comprising the entirety of signaling mediators secreted by AT were suggested (Funcke and Scherer, 2019). Overall, the term adipokinome should be used to describe the entirety of proteins and lipids, such as the secretome of AT (Trayhurn and Wood, 2004). This review focuses on the bovine AT secretome, in particular, protein, peptide, and lipid mediators secreted by adipocytes as well as the cells of the stromal vascular cell fraction in various AT depots of dairy cows in the periparturient period.

\section{Protein Adipokines}

Concerning the proteins, aside from leptin and adiponectin, the knowledge about most proteinaceous adipokines in dairy cows, and ruminants in general, is largely limited to mRNA data, whereas protein data, both for AT itself and in the circulation are scarce. One important reason for this is the lack of suitable and valid assays. Even though antisera used in western blotting and ELISA are available from commercial sources, they are hardly validated for bovine samples, and using them may result in misleading data. For western blot data, not only the antibodies but also the conditions used (linearity of signal to the amount of sample, to the dilution of the first and second antibody) should be validated and appropriate controls integrated when aiming at quantification (as recommended for example by Pillai-Kastoori et al., 2020). When using proteomics, validation of individual proteins using western blot or ELISA is often requested but can result in the dilemma of inappropriate assays that are not suitable for validation. This is certainly not limited to adipokines, and care should be taken both by authors and reviewers to support that only validated data make their way into the literature. The following section provides an overview of selected protein adipokines and cytokines. Table 1 summarizes the adipokines and their main functions discussed in this review article.

Adiponectin. Adiponectin, predominantly derived from adipocytes, is synthesized as a monomer; however, polymerization of adiponectin is essential to regulate biological activity (Wang et al., 2006). In dairy cows, adiponectin circulates mainly as a high molecular weight isoform, regardless of lactation stage (Giesy et al., 2012; Sauerwein and Häußler, 2016). The different isoforms mediate their function via different receptors (see Table 1). Decreased circulating adiponectin levels, as well as reduced biological response to adiponectin through reduced expression of adiponectin receptors (ADIPOR1 and ADIPOR2), can reduce adiponectin sensitivity (Stojanovic et al., 2020). In obese humans, reduced ADIPOR1 expression in AT was associated with reduced biological adiponectin response and consequently aggravate negative metabolic effects of low adiponectin concentrations (Rasmussen et al., 2006). Therefore, downregulation of adiponectin receptors (ADIPOR1 and ADIPOR2) mRNA abundance in subcutaneous AT (scAT) in periparturient dairy cows might suggest decreased insulin sensitivity, leading to reduced glucose uptake and increased lipolysis after parturition (Lemor et al., 2009).

The anti-inflammatory properties of adiponectin have been substantiated in dairy cows during the periparturient period, where reduced adiponectin concentrations together with increased lipolysis could enhance the inflammatory response of monocytes (Kabara et al., 2014). Moreover, adiponectin treated primary bovine monocytes suppressed upregulation of TNF- $\alpha$ gene and protein expression after LPS administration, confirming an immune-modulatory function of adiponectin (Kabara et al., 2014). Pereira et al. (2020) reported increased plasma adiponectin concentrations at d 21 and 45 postpartum $(\mathbf{P P})$ in dairy cows with persistent endometritis. Based on their overall results, adiponectin was suggested as a biomarker for early diagnosis of subclinical endometritis (Pereira et al., 2020). Adiponectin plays a key role in controlling energy metabolism by promoting insulin sensitivity, adipogenesis, and lipid storage in AT (Fu et al., 2005), lipogenesis in hepatocytes, and fatty acid (FA) $\beta$-oxidation in myocytes and hepatocytes in humans (Stern et al., 2016). For cattle, we have investigated endogenous and exogenous factors affecting the concentrations of adiponectin in various body fluids and tissues (Sauerwein and Häußler, 2016). Using an in-house developed competitive ELISA, we found that serum adiponectin concentrations exceeds those in AT (Singh et al., 2014a); however, around parturition, adiponectin concentrations in circulation as well as in various AT depots decrease in high-producing dairy cows and reach their nadir immediately after calving (Singh et al., 2014a,b). Moreover, the mRNA abundance of adiponectin receptors ADIPOR 1 and $A D I P O R 2$ in scAT was lesser than in liver during the transition from pregnancy to lactation in high-yielding dairy cows (Saremi et al., 2014). Different mRNA abun- 


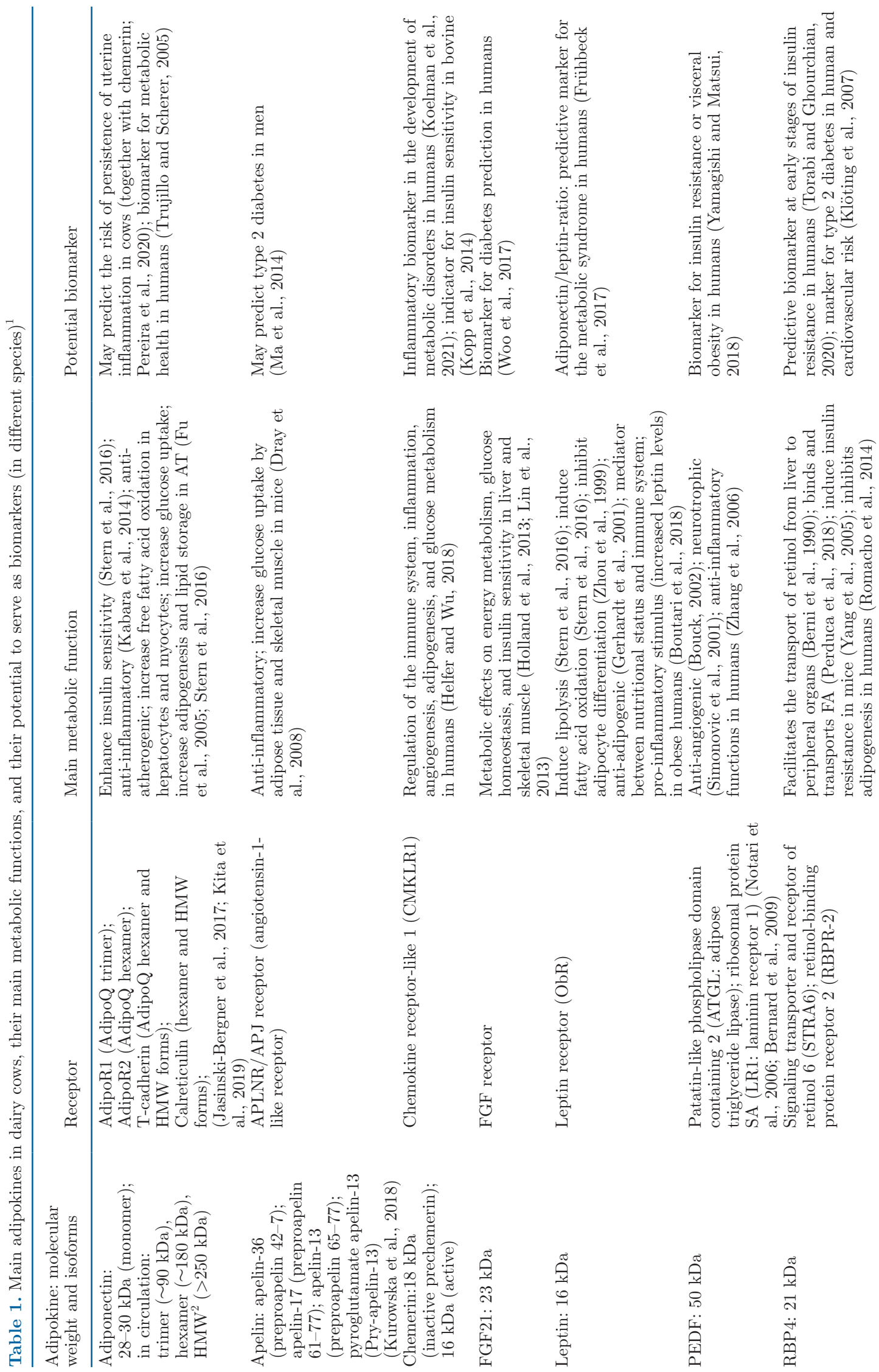




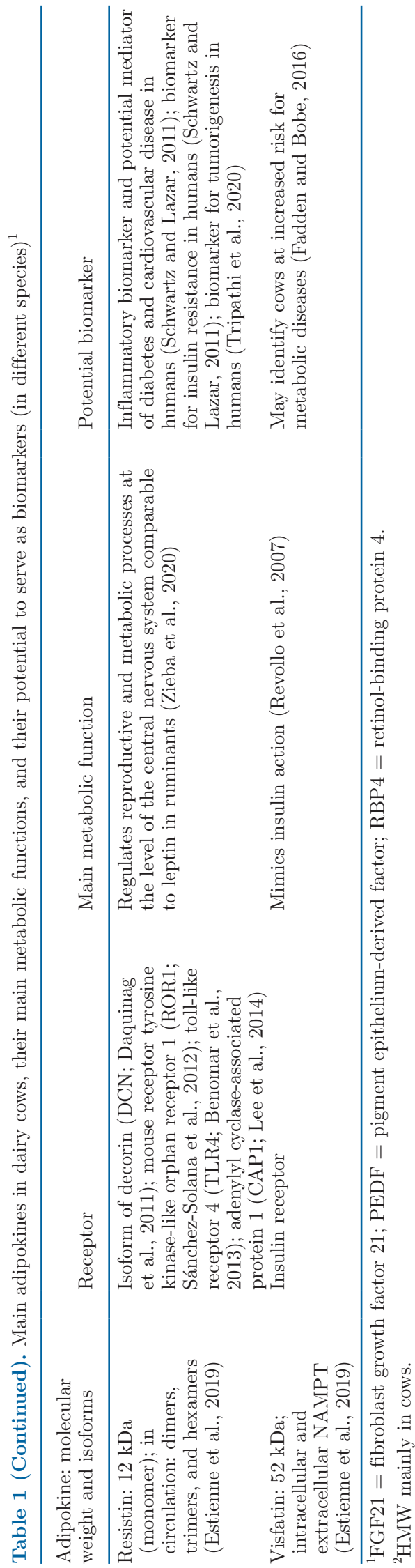

dance of ADIPOR1 and ADIPOR2 in various tissues (i.e., sc and visceral fat depots, liver, muscle, and mammary gland) suggests differential local regulation of insulin sensitivity (Saremi et al., 2014). During the dry period of dairy cows, De Koster et al. (2017) observed a negative correlation between body condition and serum adiponectin concentrations, with adiponectin values decreasing at the end of the dry period. However, comparing multiparous dairy cows with high $(>4.0)$ and normal (3.25-3.5) BCS, body condition at parturition did not affect circulating adiponectin concentrations (Mansouryar et al., 2018).

Overall, it has been suggested that lower blood adiponectin concentrations and decreased mRNA abundance in tissues around parturition contribute to increased lipolysis and decreased insulin sensitivity of peripheral tissues, both of which improve the nutritional status of dairy cows after calving (Singh et al., 2014b). Thus, the local and endocrine functions of adiponectin in dairy cows are thought to contribute to the homeorhetic adaptations in early lactation (Contreras et al., 2017).

Apelin. Apelin, another fat-derived factor, has been reported to increase glucose uptake by AT and skeletal muscle in mice (Dray et al., 2008). In addition to adipocytes, APLN mRNA and its receptor are also expressed in other tissues such as lung, heart, skeletal muscle, kidney, brain, and liver (De Falco et al., 2002). Four isoforms of apelin exist with different biological activities (see Table 1). Although, the isoforms are not fully understood, apelin-13 and pyroglutamate apelin-13 have greater activity than apelin-36 (Kurowska et al., 2018). The isoforms show different affinities for the G-protein-coupled apelin receptor APJ, an angiotensin-1-like receptor (i.e., apelin-13 binds more effectively than apelin-36; Hosoya et al., 2000). However, the longer apelin-36 is considered the physiologically active form in dairy cows (Alhussien and Dang, 2020). Using untargeted liquid chromatography in conjunction with high resolution and high accuracy mass spectrometry, 46 apelin peptides has been detected in bovine colostrum, with varying abundance between different colostrum samples (Mesmin et al., 2011). However, the biological relevance of the different apelin compositions in bovine colostrum is unclear, albeit an individual effect on calves has been suggested (Mesmin et al., 2011).

In dairy cows, apelin was detected in blood, milk, and colostrum (Mesmin et al., 2011; Aydin, 2013). However, both tissue and colostrum concentrations were reportedly greater (approximately $200 \mathrm{ng} / \mathrm{mL}$; Habata et al., 1999; Mesmin et al., 2011) compared with serum concentrations $(1-1.4 \mathrm{ng} / \mathrm{mL}$ ) in dairy cows (Weber et al., 2016a), which might result out of different assays used for the analysis. Weber et al. (2016a) showed that total serum apelin concentrations were nearly constant from 
late gestation to 100 DIM in high-yielding dairy cows and thus, did not reflect metabolic challenges around parturition.

Using an ELISA that exclusively detects apelin-36, decreased apelin-36 concentrations accompanied with decreased insulin and glucose concentrations were observed in primiparous and multiparous cows during the transition period with concomitant BCS reduction (Norvezh et al., 2019). Regarding the contradicting results to Weber et al. (2016a), Norvezh et al. (2019) suggested that the proportion of the different apelin peptides might change during the periparturient period, without affecting the overall serum apelin concentrations. Moreover, markers related to NEB in dairy cows, such as FFA, insulin, and glucose concentrations, were associated with decreasing apelin-36 serum concentrations around calving. Thus, the altered apelin-36 concentrations during the periparturient period might be involved in adaptations of dairy cows to NEB in early lactation (Norvezh et al., 2019).

Chemerin. Chemerin, encoded by the retinoic acid 2 receptor (RARRES2), is predominantly expressed and secreted by adipocytes (Reverchon et al., 2015; Helfer and $\mathrm{Wu}, 2018$ ) and hepatocytes (Krautbauer et al., 2013). Chemerin is involved in the regulation of the immune system, inflammation, angiogenesis, adipogenesis, and glucose metabolism in humans (Helfer and $\mathrm{Wu}, 2018)$. In dairy cows, plasma concentrations of chemerin range from 3.6 to $4.8 \mathrm{ng} / \mathrm{mL}$ in early lactation and then steadily decrease until wk 20 of lactation (Mellouk et al., 2019). The mRNA abundance of RARRES2 in bovine scAT was related to BCS and yearling weight (Lindholm-Perry et al., 2012), adipocyte differentiation (Song et al., 2010), and body fat mobilization (Elis et al., 2013, 2016; Mellouk et al., 2019). Fu et al. (2016) investigated the effects of chemerin treatment on mature adipocytes as well as de-differentiated bovine intramuscular preadipocytes in vitro. They found that chemerin and its receptor (G-protein-coupled chemerin-like receptor 1) were predominantly expressed in bovine intramuscular adipocytes and were downregulated during adipocyte lipolysis, whereas they were reversed during preadipocyte differentiation (Fu et al., 2016). Exposure to chemerin induced lipolysis in intramuscular mature adipocytes in vitro, as indicated by increased glycerol levels, FFA, and upregulated expression of the lipolysiscritical factors hormone-sensitive lipase, lipoprotein lipase (LPL), and leptin (Fu et al., 2016). Previous in vivo studies (Suzuki et al., 2012a,b) reported the metabolic and endocrine changes in response to chemerin in sheep. They found that chemerin analog regulated insulin secretion related to glucose metabolism (Suzuki et al., 2012b) and treatment with chemerin analog upregulated RARRES2 mRNA abundance in bovine dif- ferentiated adipocytes (Suzuki et al., 2012a). Moreover, treatment of bovine adipocytes with nicotinic acid (10 $\mu M)$ for $24 \mathrm{~h}$ resulted in increased mRNA abundance of RARRES2 compared with the untreated controls (Kopp et al., 2014). Kopp et al. (2014) assumed that niacin supplementation might improve insulin sensitivity or adipocyte metabolism, suggesting chemerin as a potential indicator for insulin sensitivity.

Fibroblast Growth Factor 21. Fibroblast growth factor 21, a member of the endocrine branch of the FGF superfamily, has important effects on energy homeostasis, glucose, and lipid metabolism, and insulin sensitivity (Kharitonenkov et al., 2005). The FGF21 acts through the FGF receptor (FGFR) with the transmembrane protein $\beta$-Klotho as an essential co-factor activating FGFR (Itoh, 2010). The liver is considered the main site of FGF21 production in mice, where production is induced by fasting or ketogenic diets (Badman et al., 2007; Inagaki et al., 2007) and by activation of peroxisome proliferator-activated receptor (PPAR) $\alpha$, cAMP-responsive element-binding protein $\mathrm{H}$, and the deacetylase sirtuin 1 (Fisher and Maratos-Flier, 2016). In addition, FGF21 is considered as an adipokine (Itoh, 2014), with the adipokine adiponectin as a downstream effector of FGF21 mediating the metabolic effects of FGF21 on energy metabolism, glucose homeostasis, and insulin sensitivity in liver and skeletal muscle (Holland et al., 2013; Lin et al., 2013). However, a bolus and chronic administration of FGF21 did not provide evidence for FGF21 stimulation of adiponectin in earlylactating dairy cows (Krumm et al., 2019). Plasma FGF21 levels increase abruptly in periparturient dairy cows at the beginning of lactation and remain elevated during the energy deficit of early lactation (Schoenberg et al., 2011). The mRNA abundance of FGF21 was detectable in scAT on $\mathrm{d}-40$ and 7 relative to calving in multiparous cows but was much lower than in the liver ( $\leq 4 \%$; Schoenberg et al., 2011). In prepubertal dairy heifers, FGFR1c was the dominant expression in scAT and perirenal AT among all FGFR transcripts, and that of $K L B$ mRNA was more abundantly expressed in AT than in the liver (Schoenberg et al., 2011). The transition from late gestation to early lactation did not affect the abundance of FGFR1c mRNA in scAT in multiparous cows (Schoenberg et al., 2011) and in dairy cows receiving the PPAR agonist CLA (Sadri et al., 2014). However, protein data of FGF21 in bovine AT are lacking so far. Therefore, studies on the regulation of FGF21 expression in different AT depots and a possible endocrine role of AT as a source of systemic FGF21 in cattle as well as on FGF21 protein in bovine AT may be particularly relevant.

Leptin. The protein hormone leptin is primarily known as an adipokine; however, leptin is also ex- 
pressed and secreted by several other tissues, including muscle, mammary gland, placenta, and gastric mucosa (Chilliard et al., 2001). Leptin acts in an autocrine, paracrine, and endocrine manner and modulates food intake and energy expenditure, predominantly via hypothalamic signals in the CNS (Liefers et al., 2005). Leptin is ubiquitously encoded by the $L E P$ gene and plays a central role in regulating body energy homeostasis, with concentrations correlating with body fat content (Chilliard et al., 2001). As known from human studies, leptin induces lipolysis and FA oxidation during periods of suppressed feed intake (Stern et al., 2016). In addition, an inhibitory effect on adipocyte differentiation has been reported for this adipokine in rats (Zhou et al., 1999), which directly contributes to the antiadipogenic effects of chemokines observed in cultured human adipocytes (Gerhardt et al., 2001). Ingvartsen and Boisclair (2001) reviewed the effects of low leptin levels due to starvation as well as exogenous leptin administration on immune parameters in rodents. In mice, exogenous leptin administration inverted the inhibitory effects of starvation on T-cells (Lord et al., 1998). In this context, it has been suggested that leptin is a mediator between nutritional status and the immune system (Friedman and Halaas, 1998). Leptin mainly acts in a pro-inflammatory way, affecting both the immune cell development and function (Kiernan and Maclver, 2021). Because the immune system of dairy cows is prone to dysfunctions in the periparturient period (reviewed by Sordillo 2016), leptin deficit in early lactation might contribute to the development of depressed immunity (Ingvartsen and Boisclair, 2001). A possible immunosuppressing effect of leptin therapy on immune cells, as shown in starving mice (Lord et al., 1998), may offer advantages for the strained metabolic situation in early-lactating dairy cows.

In ruminants, AT is the major supplier of plasma leptin (Chilliard et al., 2001) with varying mRNA abundance in different subcutaneous and visceral AT (Saremi et al., 2014). With the development of valid assays, both RIA (Ehrhardt et al., 2000; Delavaud et al., 2000) and ELISA (Kauter et al., 2000; Sauerwein et al., 2004), leptin concentrations were quantified in ruminants. In dairy cows, plasma leptin concentrations are greatest during the dry period (Holtenius et al., 2003), whereas they decrease around the time of parturition due to lesser leptin secretion from AT (Block et al., 2001). Both leptin concentrations in plasma and cerebrospinal fluid decreased until calving and remained low in early lactation when compared with values before calving (Laeger et al., 2013). Given that leptin reduces feed intake in ruminants when binding to its receptors located in the hypothalamus (Morrison et al., 2001), Laeger et al. (2013) assumed that reduced circulating leptin stimulates hyperphagia during early lactation. Both primiparous and multiparous cows exhibited decreasing plasma leptin concentrations during the transition period, which was accompanied by decreasing mRNA abundance of LEP in scAT from the tail head region (Saremi et al., 2014). This may promote a rapid return to normal DMI within this period (Contreras et al., 2017). Moreover, Sadri et al. (2011) observed inverse leptin concentrations with the greatest NEFA concentrations in the blood of dairy cows one week after parturition, due to either NEB or increased turnover rate during lactation. A greater decrease in plasma leptin was observed in over-conditioned dairy cows during the last week before and the first week after calving compared with cows with normal body fatness, postulating that plasma leptin was closely related to body fatness in early-lactating dairy cows (Kokkonen et al., 2005). Furthermore, leptin was greater in dairy cows with a greater degree of periparturient lipomobilization than normally conditioned cows due to their over-conditioning in the antepartum (AP) period (Schuh et al., 2019). Leptin resistance during gestation prevents reduction of feed intake in dairy cows; however, after parturition, leptin sensitivity seems to increases due to an increased expression of leptin receptors (Liefers et al., 2005). Albeit the mechanisms of leptin resistance require further investigations, the reduction of plasma leptin around parturition likely contributes to the adaptive metabolism of early-lactating dairy cows (Ehrhardt et al., 2016).

Pigment Epithelium-Derived Factor. Being one of the major biological active secretion products of human adipocytes PEDF has anti-angiogenic (Bouck, 2002), neurotrophic (Simonovic et al., 2001), and antiinflammatory functions (Zhang et al., 2006). Treatment with PEDF-induced insulin resistance in human adipocytes and skeletal muscle cells (Famulla et al., 2011). It has been suggested as a marker of body mass changes, because weight loss has been associated with decreased serum PEDF in both animal models of obesity and obese humans (Crowe et al., 2009; Sabater et al., 2010). Based on the expression profile of SERPINF1 mRNA during $13 \mathrm{~d}$ of differentiation of primary bovine preadipocytes, adipocytes have also been shown to be a source of PEDF synthesis in AT of dairy cows (Sadri et al., 2018). Regarding the putative functional receptors of PEDF (see Table 1), ATGL is required for the PEDF-induced lipolysis and triglycerides degradation in liver and adipocytes (Chung et al., 2008; Borg et al., 2011). The lactation-induced increase in SERPINF1 mRNA abundance in scAT was attenuated by CLA supplementation and coincided with reduced serum concentrations of PEDF in multiparous cows 21 DIM (Sadri et al., 2018). When comparing different tissues 
of primiparous cows, SERPINF1 mRNA was greatest in the liver, followed by scAT (tail head, withers, and sternum) and then visceral AT (omental, mesenteric, and retroperitoneal). However, the similarities between the time course of serum PEDF concentrations and its mRNA abundance in scAT observed in multiparous cows suggest that AT is relevant in terms of circulation and thus may indicate a regulatory role for AT rather than liver for PEDF in dairy cows (Sadri et al., 2018). The abundance of SERPINF1 mRNA in scAT was constant between the different serum-metabotypes of periparturient over-conditioned (BCS >3.75) dairy cows (Sadri et al., 2021). Protein data of PEDF in bovine AT are lacking so far; however, the limited available (mRNA) data support a regulatory role for PEDF in dairy cows. Studies on a possible endocrine role for $\mathrm{AT}$ as a source of systemic PEDF and its potential contribution in lactation-driven body fat loss in periparturient dairy cows may be particularly relevant.

Retinol-Binding Protein 4. The protein RBP4 is expressed in adipocytes, myocytes, macrophages, and other tissues and cells (Yang et al., 2005; Broch et al., 2010; Kuperman et al., 2011). The RBP4 facilitates the transport of retinol from the liver to peripheral organs (Berni et al., 1990; Tsutsumi et al., 1992). Beyond retinol transport, RBP4 binds and transports FA (Perduca et al., 2018). As a member of a gene set, RBP4 is involved in intramuscular adipocyte lipid metabolism in bovine skeletal muscle (De Jager et al., 2013). In mice, RBP4 has been shown to induce insulin resistance (Yang et al., 2005), and serum concentrations of $\mathrm{RBP} 4$ correlated with the extent of insulin resistance in humans with impaired glucose tolerance, obesity, or type 2 diabetes (Graham et al., 2006; Kilicarslan et al., 2020). It has been shown that RBP4 plays a role in the degradation of very low-density lipoproteins and the formation of small dense low-density lipoproteins in humans (Usui et al., 2009; Wu et al., 2012). Increased RBP4 levels were associated with increased fat deposition and altered FA profiles (i.e., greater polyunsaturated and lesser saturated proportions of FA; Liu et al., 2019). In nonpregnant, nonlactating dairy cows, plasma concentrations of RBP4 measured by western blot (around $45 \mu \mathrm{g} / \mathrm{mL}$ ) decreased immediately after calving and returned to pre-calving concentrations by 2 wk after calving (Abd Eldaim et al., 2010). The decrease in plasma RBP4 may be due to influx into the mammary gland after calving, although other factors such as protein intake and inflammatory responses may also influence RBP4 synthesis in dairy cows (Selim et al., 2015). Analyzing the dietary effect on circulating RBP4 levels, Lindberg et al. (1999) observed increasing serum RBP4 concentrations after crude protein supplementation during the dry period in dairy cows
(Lindberg et al., 1999). A recent study in crossbred bulls showed that RBP4 was expressed at the mRNA and protein levels in various AT depots (subcutaneous, omental, perirenal, and intestinal AT) as well as in the liver (Liu et al., 2019). In dairy cows, Rezamand et al. (2012) observed a positive association between the mRNA abundance of $R B P 4$ and the pro-inflammatory cytokine $T N F$, in a tissue-specific manner (weak relationship in AT, strong relationship in liver) during the periparturient period, suggesting a role for RBP4 in the inflammatory processes in dairy cows. Albeit RBP4 is a crucial predictor for insulin resistance in mice and humans, the mechanisms by which RBP4 induces insulin resistance are not fully understood.

Resistin. Known as an adipocyte-derived factor, resistin belongs to the family of proteins found in inflammatory zone 3 (Steppan et al., 2001), mediating insulin resistance in mice and serving as a biomarker for insulin resistance in humans (Schwartz and Lazar, 2011). Comparable to leptin, resistin regulates reproductive and metabolic processes at the level of the CNS in ruminants (Zieba et al., 2020). Although, the receptor for resistin is unknown, several potential receptors have been proposed (see Table 1). In addition, resistin activates signaling pathways in various tissues, such as phosphatidylinositol 3'-kinase/protein kinase B (Akt), mitogen-activated protein kinases (MAPK; ERK1/2 and p38), signal transducer and activator of transcription 3, and PPAR (Rak et al., 2017). The source of resistin is species-specific: in mice, cattle, and sheep, resistin is mainly synthesized by adipocytes, whereas in humans, monocytes and macrophages are the main sources (Mellouk et al., 2017).

In high-yielding dairy cows, resistin concentrations increased before parturition and peaked during the first week of lactation (Reverchon et al., 2014; Weber et al., 2016a). Moreover, circulating resistin concentrations were greater in cows fed low-energy diets compared with over-conditioned cows (Mellouk et al., 2017). The positive correlation of plasma resistin concentrations with circulating FA and backfat thickness in dairy cows fed different energy levels (Mellouk et al., 2017) suggests that resistin is involved in periparturient lipolytic processes (Reverchon et al., 2014; Weber et al., 2016a). Comparable to circulating concentrations, RETN mRNA abundance and protein concentrations were elevated in scAT of cattle one week after calving (Reverchon et al., 2014). During the periparturient period, resistin concentrations in cerebrospinal fluid in dairy cows remained unchanged, suggesting that resistin does not play a major role in the central control of feed intake around parturition (Laeger et al., 2013).

Recombinant resistin was able to modulate steroidogenesis by decreasing the secretion of progesterone 
and estradiol from primary bovine granulosa cells and stimulated basal proliferation of granulosa cells in cows (Maillard et al., 2011). Thus, resistin may be a metabolic signal involved in reproductive functions in cattle (Maillard et al., 2011). Due to its effects on immune cells, such as stimulation of inflammatory cytokine synthesis, resistin was described as an inflammatory marker in humans (Schwartz and Lazar, 2011). Furthermore, in humans resistin was suggested as a potential marker for diabetes, insulin resistance, and cardiovascular diseases (Schwartz and Lazar, 2011). However, because the main sources of resistin were described to be speciesspecific (Mellouk et al., 2017), the potential of resistin to serve as a biomarker for metabolic or inflammatory dysfunctions as already described in humans needs to be clarified in dairy cows.

Visfatin. Visfatin, a multifunctional protein, is also known as nicotinamide phosphorybosyltransferase (NAMPT) or pre-B cell colony-enhancing factor in mammals (PBEF). In humans and mice, visfatin is highly enriched in visceral AT (Fukuhara et al., 2005) and its plasma concentrations have been positively associated with obesity (Berndt et al., 2005). Visfatin mimics insulin actions via the insulin receptor (Revollo et al., 2007). In mammals, 2 forms of visfatin exist (see Table 1). Although the intracellular form plays an important role in sirtuin activation in mitochondria and functions as an $\mathrm{NAD}^{+}$biosynthetic enzyme, the function of the extracellular isoform is controversial (Estienne et al., 2019).

In addition to AT, visfatin is expressed in bone marrow, liver, muscle, female reproductive organs, and various other tissues and is linked to the regulation of energy metabolism, growth, and development in humans (Shen et al., 2020). In humans, visfatin is involved in glucose homeostasis, which lowers plasma glucose (Fukuhara et al., 2005), inflammation, various metabolic and stress responses, and cellular energy metabolism (Zhang et al., 2011; Reverchon et al., 2016).

After calving, NAMPT mRNA abundance tends to be decreased in the scAT of dairy cows when compared with values AP (Lemor et al., 2009). Furthermore, the mRNA abundance of NAMPT in the scAT of these cows was negatively correlated with NEFA and BHB concentrations, which coincided with unchanged insulin receptor mRNA abundance around parturition (Lemor et al., 2009), proposing a possible role of visfatin in insulin resistance in periparturient dairy cows. In addition to decreased NAMPT mRNA abundance in scAT from PP to AP levels, decreasing mRNA abundance in retroperitoneal AT after parturition was suggested to reflect a tissue-dependent mechanism to decrease insulin-stimulated lipogenesis and increase lipolysis (Weber et al., 2016b). The NAMPT mRNA was positively cor- related with ADIPOR $1 \mathrm{mRNA}$ in the scAT of dairy cows, likely representing a local regulatory mechanism (Weber et al., 2016b). Along with other adipokines, such as adiponectin, leptin, and resistin, all of which are expressed in the placenta of cows, visfatin has been proposed to play a coordinating role in promoting intrauterine growth in calves (Shen et al., 2020). Fadden and Bobe (2016) were the first to report circulating visfatin in dairy cows. Using a competitive enzyme immunoassay, they demonstrated that decreasing serum visfatin concentrations 3 wk before calving may contribute to homeorhetic adaptations due to parturition. Visfatin is elevated in association with retained placenta and other metabolic diseases (e.g., metritis and ketosis), therefore, it may help to identify cows at increased risk for metabolic diseases (Fadden and Bobe, 2016).

Other Adipokines. There are several other adipokines, such as lipocalin-2, vaspin, omentin, follistatinlike 1 , secreted protein acidic and rich in cysteine, secreted frizzled-related protein 5, C1q/TNF-related proteins, family with sequence similarity to 19 member A5, wingless-type inducible signaling pathway protein-1, progranulin, nesfatin-1, and plasminogen activator inhibitor-1, whose role in humans has been thoroughly investigated; however, limited research has been conducted to assess the function of these adipokines in dairy cattle. Because a detailed discussion of these adipokines in other tissues is beyond the scope of this review, they are not discussed further here.

\section{Cytokines}

Tumor Necrosis Factor $\alpha$. Tumor necrosis factor $\alpha(25 \mathrm{kDa}, 233 \mathrm{AA})$, a multifunctional regulatory adipocytokine, is produced in AT, derived from resident macrophages and monocytes and possibly adipocytes (Hotamisligil et al., 1993; Olefsky and Glass, 2010). It has a central role in inflammation, production of other cytokines, lipolysis, and reduction of insulin sensitivity in animal models of obesity and insulin resistance (Uysal et al., 1997; Kushibiki et al., 2002; Wellen and Hotamisgli, 2005), whose main effects are mediated by its receptors, TNFR1 and TNFR2 (Sethi et al., 2000).

The mRNA abundance of $T N F-\alpha$ in scAT of dairy cows was found to increase from wk $8 \mathrm{AP}$ to the day of calving; however, this was not reflected by greater TNF- $\alpha$ concentrations in plasma (Sadri et al., 2010), pointing that TNF- $\alpha$ of AT origin might act locally with evidence from human medicine that it acts predominantly as a local factor (Ronti et al., 2006; Frühbeck et al., 2014). The abundance of TNF mRNA in bovine scAT was dependent on parity (Saremi et al., 2014), remaining unchanged when considering multiparous cows from d $21 \mathrm{AP}$ to $252 \mathrm{DIM}$, or increasing in 
primiparous cows from 1 to 42 DIM. It is not clear to what extent TNF- $\alpha$ of AT origin is contributing to the inflammatory signals that are elevated in dairy cows around parturition (McNamara and Huber, 2018), though these signals are not always pathological (Bradford and Swartz, 2020). Lactating cows with a high BCS ( $\geq 3.5$ vs. 2.5-2.7) had greater concentrations of TNF- $\alpha$ in plasma (O'Boyle et al., 2006), whereas its mRNA abundance in scAT did not differ in periparturient over-conditioned dairy cows $(\mathrm{BCS}>3.75)$ of divergent serum-metabotype (Sadri et al., 2021). The abundance of TNF mRNA was positively associated with adipocyte size in dairy cows at the end of gestation and differed among the AT depot. The greater mRNA abundance of $T N F$ in the subcutaneous and omental depots than in the intrapelvic depot (Depreester et al., 2018), may suggest potential differences in inflammatory characteristics depending on the anatomical location of AT depots. Adipose tissue depot-dependent differences were also found in terms of TNFRSF1A mRNA abundance, being greater in retroperitoneal AT than in scAT on d 42 AP and d 21 PP (Weber et al., 2016a). A continuous low dose infusion of recombinant bovine TNF- $\alpha$ into a scAT depot of lactating dairy cows had no measurable effect on metabolism, whereas a counterregulatory anti-inflammatory response (increased IL-10 protein in the contralateral AT depot) was observed in the liver and the AT (Martel et al., 2014), pointing to an apparent homeostatic response in the opposite direction (Bradford and Swartz, 2020). In most studies, AT of transition cows is characterized by greater gene expression of the pro-inflammatory cytokine TNF (e.g., Contreras et al., 2015; Selim et al., 2014). However, it is not clear to what extent TNF- $\alpha$ derived from AT contributes to the inflammatory response elevated around parturition in dairy cows and whether this cytokine affects either locally or systemically the metabolism of the cows.

Interleukin-6. Interleukin-6, a pluripotent cytokine, is produced by several tissues and cells, such as macrophages, endothelial cells, adipocytes, skeletal muscle, and fibroblasts (Tanaka et al., 2014). The biological functions of IL- 6 are mediated through binding to the IL-6 receptor (Garbers et al., 2012). Interleukin-6 has both pro- and anti-inflammatory effects, with a central role in the regulation of inflammation, immune responses, host defense mechanisms, multiple aspects of metabolism, including glucose disposal, lipolysis, oxidative metabolism, energy expenditure, and insulin resistance (Makki et al., 2013); though, data in the context of its role in both insulin resistance and obesity in human medicine is controversial and unresolved (Taylor, 2021). It was demonstrated in rodents that the source of IL- 6 production plays a major role in the physiological regulation of metabolism (Han et al., 2020). Adipose tissue macrophages (ATM) and adipocytes are regarded as the main source of IL-6 within white AT (Weisberg et al., 2003). In humans, adiposederived IL-6 is an important source of circulating IL-6, as approximately a third of circulating IL- 6 in healthy individuals is estimated to originate from AT (Makki et al., 2013). It has also been regarded as a marker for visceral adiposity because visceral AT releases greater IL-6 than scAT in humans (Fried et al., 1998). Whether AT-derived IL- 6 acts in the same manner in dairy cows is currently unknown. Comparing different fat depots from primiparous cows, the abundance of $I L 6 \mathrm{mRNA}$ in scAT from the tail head and withers was decreased from 1 to 105 DIM, whereas that of the liver was increased (Saremi et al., 2014). Moreover, the mRNA abundance of IL6 was upregulated in AT depots with enlarged adipocytes in dairy cows at the end of gestation and was influenced by the AT depot, with lesser abundance in scAT than in other depots (i.e., omental, mesenteric, intrapelvic, and perirenal; Depreester et al., 2018). Lopreiato et al. (2018) investigated the effect of dietary energy level in nonlactating and nonpregnant Holstein cows on the mRNA abundance of IL 6 and NFKB1 in scAT. Together with upregulated IL 6 and NFKB1 mRNA in scAT $2 \mathrm{~h}$ after TNF- $\alpha$ incubation in vitro, greater mRNA abundance in control than in cows receiving a higher-energy diet, suggests for a rapid inflammatory response (Lopreiato et al., 2018). However, the abundance of $I L 6 \mathrm{mRNA}$ was not affected by overfeeding AP in transition dairy cows (Selim et al., 2014). The mRNA abundance of $I L 6$ on $d 21$ and $42 \mathrm{PP}$ in scAT of multiparous cows was positively correlated with BCS loss, being greatest in high BCS loss, intermediate in moderate BCS loss, and least in low BCS loss cows (Dirandeh et al., 2020).

Albeit levels of circulating pro-inflammatory cytokines such as IL-6 varies between different studies in the periparturient period of dairy cows, concentrations generally increased during the first week after parturition (reviewed by Kuhla, 2020). However, to what extent IL-6 from AT contributes to the peak right after calving in dairy cows, remains currently open.

Monocyte Chemoattractant Protein-1. Monocyte chemoattractant protein 1 is secreted in response to signals such as pro-inflammatory cytokines (Deshmane et al., 2009). Being a potent chemotactic factor for monocytes (Deshmane et al., 2009), MCP-1 acts as a pro-inflammatory chemokine (Christiansen et al., 2005 ), including in AT as reported in mice (Kanda et al., 2006). The MCP-1 is secreted by various cell types, such as macrophages and endothelial cells, but also by human preadipocytes and isolated mature adipocytes (Gerhardt et al., 2001). 
In dairy cows, MCP-1 is encoded by chemokine (CC motif) ligand 2 (CCL2) and was upregulated in scAT after calving when compared with p.p. levels (Mann et al., 2016). Furthermore, Contreras et al. (2015) observed greater CCL2 mRNA abundance in AT of cows with displaced abomasum compared with healthy cows. Specifically, visceral AT depots expressed more $M C P$ 1/CCL2 mRNA than the scAT in early-lactating dairy cows (Contreras et al., 2015; Häussler et al., 2015).

Acting as a chemokine, MCP-1 is one of the first molecules mobilized in response to inflammatory challenges (Tang and Wang, 2018). In humans, increased expression of MCP-1 in cells from the stromal vascular fraction in AT recruit macrophages infiltrating into AT leading to a low-grade inflammatory status (Capurso and Capurso, 2012). De Koster et al. (2018b) confirmed the chemoattractant role of CCL2 for ATM in bovine scAT during the first week after calving; however, the ATM proportion was not related to the gene expression of other pro-inflammatory cytokines ( TNF or IL6). Macrophages can be categorized into classically activated, M1 macrophages being involved in inflammatory processes (releasing pro-inflammatory cytokines) and alternatively activated, M2 macrophages playing a role in immunosuppressive activities (Hill et al., 2014). The results from De Koster et al. (2018b) point to an immunosuppressive role of CCL2 in bovine scAT; however, further research is necessary to clarify the function of ATM, the processes leading to ATM infiltration, and the respective role of MCP-1 or CCL2 in this context.

\section{Lipid Adipokines}

It is long known that AT contains and releases lipids other than FA, such as steroids (McCracken, 1964). The notion that these lipids may not only be passively incorporated and released but also partly synthesized and metabolized in AT also emerged decades ago, for example, as reviewed by Richelsen et al. (1992) for eicosanoids. In addition to eicosanoids and steroids, the current list of lipid adipokines comprises ceramides, endocannabinoids, FA esters of hydroxy FA, lysophosphatidic acids, and sphingolipids (Funcke and Scherer, 2019), as well as oxysterols ( $\mathrm{Li}$ et al., 2014) and bile acids (Jäntti et al., 2014). In contrast to proteins, analytical methods detecting these lipid adipokines developed in other species can principally be transferred for use in bovine samples. In addition, with the rapid development of lipidomics technologies, great progress can be expected also for lipid adipokines from targeted approaches. In this review, the endocannabinoids, FA, and steroids are in focus.

Endocannabinoids. The endocannabinoid (eCB) system consists of endogenous cannabinoids, cannabi- noid receptors (CNR1 and CNR2), and the enzymes responsible for the synthesis and degradation of eCB (Lu and Mackie, 2016). Anandamide ( $N$-arachidonoylethanolamine, AEA) and 2-arachidonoylglycerol (2AG) are the 2 major eCB as ligands of cannabinoid receptors (Spoto et al., 2006; De Petrocellis and Di Marzo, 2009). The eCB system is a central regulator of metabolism and energy homeostasis by regulating energy intake and expenditure (Nogueiras et al., 2009; Rakotoarivelo et al., 2021). Functions of the eCB system include immune modulation, modification of cell proliferation, and preservation of energy-storing reservoirs (reviewed by Myers et al., 2021). Inflammatory responses can be activated by the cCB system depending on the tissue, the eCB, and their receptors (Myers et al., 2021). Cannabinoid receptors are expressed in immune cells that can be affected by cannabinoid analogs (Tanasescu and Constantinescu, 2010). Although CNR1 are found in the CNS and in some peripheral tissues, including immune cells, CNR2 are mainly expressed by immune cells, such as B-cells and natural killer cells (Pertwee, 1997; Pertwee and Ross, 2002). In mammal AT, activation of the eCB system promotes lipogenesis and adipogenesis, but inhibits lipolytic activity (Myers et al., 2021). Plasma concentrations of AEA and 2AG were 2 - to 2.3-fold greater during early lactation (7-28 DIM; $3.0 \pm 0.94 \mathrm{nmol} / \mathrm{mL})$ compared with d $7 \mathrm{AP}(1.5 \pm 0.94$ $\mathrm{nmol} / \mathrm{mL}$ ) in dairy cows (Kuhla et al., 2020). Moreover, Zachut et al. (2018) reported that concentrations of AEA and $2 \mathrm{AG}$ in scAT were increased at the beginning of lactation in cows exhibiting high $\mathrm{PP}$ weight loss ( $>8 \%$ during the first month PP) but not in the low weight loss group. They concluded that the activation of the eCB system in AT is most likely associated with a metabolic response of greater lipolysis, BW loss, and AT inflammation in PP dairy cows, which is a part of the metabolic adaptations related to the onset of lactation (Zachut et al., 2018). There is growing evidence of the effects of eCB on the control of feed intake and energy metabolism in dairy cattle (Kuhla et al., 2020). Thus, the eCB system may play an important role in early-lactating dairy cows by increasing feed intake, decreasing adipocyte lipolysis, and alleviating acute inflammation (Kuhla et al., 2020). Due to its positive effect on appetite, adipogenesis, lipogenesis as well as the suppressive properties on lipolysis and AT inflammation, the eCB system is supposed to have beneficial effects during the periparturient period in dairy cows (Myers et al., 2021). However, further research is warranted to explore the relationship between the eCB system and metabolic adaptation in dairy cattle.

Free Fatty Acids and their Receptors. Periparturient dairy cows experience a period of energy deficit after parturition that can lead to excessive lipolysis, 
releasing FFA from AT triglyceride molecules into the bloodstream where they are transported by albumin and Fetuin-A (also named $\alpha$-2-Heremans-Schmid glycoprotein) for use in other tissues as fuel or excreted in milk fat (Contreras and Sordillo, 2011; De Koster et al., 2018a; Strieder-Barboza et al., 2018). Free FA are not only an important direct source of energy but also function as signaling molecules in the regulation of various physiological processes (Hara et al., 2013). RodríguezCarrio et al. (2017) summarized several functions of FFA, such as its effect on the macrophage, adipocyte or endothelial cell gene expression, and modulation of chemokine and cytokine production. In periparturient cows, stearic acid, palmitic acid (both SFA), and oleic acid (MUFA) were the major FA of scAT (Douglas et al., 2007).

The functions of FFA are mediated by several FFA receptors (FFAR), which belong to the class of G protein-coupled receptors (Ichimura et al., 2014). Short-chain FA (acetate, propionate, and butyrate), are important substrates in ruminant energy metabolism, with propionate serving as the primary gluconeogenic substrate in ruminants (Allen et al., 2005). Short-chain FFA activate FFAR2 (GPR43) and FFAR3 (GPR41), whereas medium- and long-chain FFA are ligands for FFAR1 (GPR40) and FFAR4 (GPR120), respectively; in addition, GPR84 is activated by medium-chain FFA (Hara et al., 2014; Ichimura et al., 2014). In rodent models, FFAR1 is involved in insulin (Meidute Abaraviciene et al., 2013) and glucagon (Flodgren et al., 2007) secretion in pancreatic islets, whereas FFAR2 increases lipid accretion and reduces lipolysis (Hong et al., 2005). There is evidence for the role of FFAR4 in mediating increased adipogenesis, lipogenesis as well as increased insulin sensitivity and anti-inflammatory processes (Ichimura et al., 2014). The various functions of FFAR in livestock such as pigs, chickens, and ruminants have been reviewed by Mielenz (2017). In general, FFAR has been reported to be involved in adipocyte differentiation, anti-inflammatory processes, nerve activation, and taste preferences (Hara et al., 2013).

In multiparous dairy cows, the mRNA abundance of FFAR1, FFAR2, and FFAR3 varied in different AT depots, muscle, liver, and mammary glands during early lactation (Friedrichs et al., 2014). Comparing early and late lactation, the FFAR 3 mRNA abundance was greater in the scAT from early-lactating cows (Lemor et al., 2009). Being involved in the monitoring of energy storage and its relationship to leptin synthesis, FFAR3 abundance has been suggested to increase after calving in response to NEB when insulin and leptin concentrations are low (Accorsi et al., 2005). However, no effect of insulin on the mRNA abundance of FFAR3 was detected in sc and retroperitoneal AT bovine explants
(Hosseini et al., 2010). Moreover, greater FFAR2 and FFAR3 mRNA abundance were observed in visceral AT depots, such as mesenterial, omental, retroperitoneal AT depots (except for FFAR2 with low mRNA abundance in retroperitoneal AT), compared to scAT from sternum, withers, and tail head region in dairy cows (Friedrichs et al., 2014). Visceral adipocytes are metabolically more active and sensitive to lipolysis than subcutaneous ones (Capurso and Capurso, 2012) and showed a greater insulin response after parturition (Kenéz et al., 2019), all of which could be related to the FFA and FFAR interaction. Although, the presence of FFAR has been studied in bovine AT, further studies are needed to reveal the function of FFAR in bovine adipocytes as well as the mechanisms behind the FFA and FFAR interaction.

Steroids. Steroid hormones, such as sex steroids, mineralocorticoids, and glucocorticoids, are derivates of cholesterol synthesized mainly in the gonads, placenta, and adrenal cortex (Holst et al., 2004). In addition to their endocrine effects, steroids can act via paracrine, autocrine, and intracrine mechanisms (Labrie, 1991). Due to their lipophilic character, steroid hormones can be stored in AT and also metabolized depending on the local enzyme setting (Deslypere et al., 1985; Dalla Valle et al., 2006). Murine adipocytes possess all components involved in cholesterol transport and steroidogenesis, indicating de novo steroid biosynthesis in adipocytes ( $\mathrm{Li}$ et al., 2014). Figure 1 shows the main steroid biosynthetic pathways and the relevant enzymes involved in steroid metabolism. Steroids synthesized or metabolized in AT mediate local effects that exhibit depot-specific differences but can also influence overall metabolism, as reported in humans (Bélanger et al., 2002). Furthermore, peripheral steroid metabolism in humans can be altered by either excessive AT accumulation (Bélanger et al., 2002) or lipolysis (Newell-Fugate, 2017), both playing critical roles in energy metabolism as well as inflammatory processes in dairy cows (Contreras et al., 2018). In the periparturient period of dairy cows, in addition to FA, steroids that are stored and locally metabolized in AT may be released into the circulation during mobilization of body fat reserves (Hamudikuwanda et al., 1996; Rodrigues et al., 2011). However, the role of AT in steroid metabolism in cattle during increasing lipolysis around the periparturient period is largely unknown.

Alizadeh et al. (2016a) investigated the mRNA abundance of STAR and CYP11A1 in subcutaneous and visceral AT during late pregnancy and early lactation in high-yielding dairy cows. Both enzymes initiate steroidogenesis, their presence in tissue points to either local steroid metabolism (STAR) or de novo steroid synthesis (CYP11A1). The absence of CYP11A1 


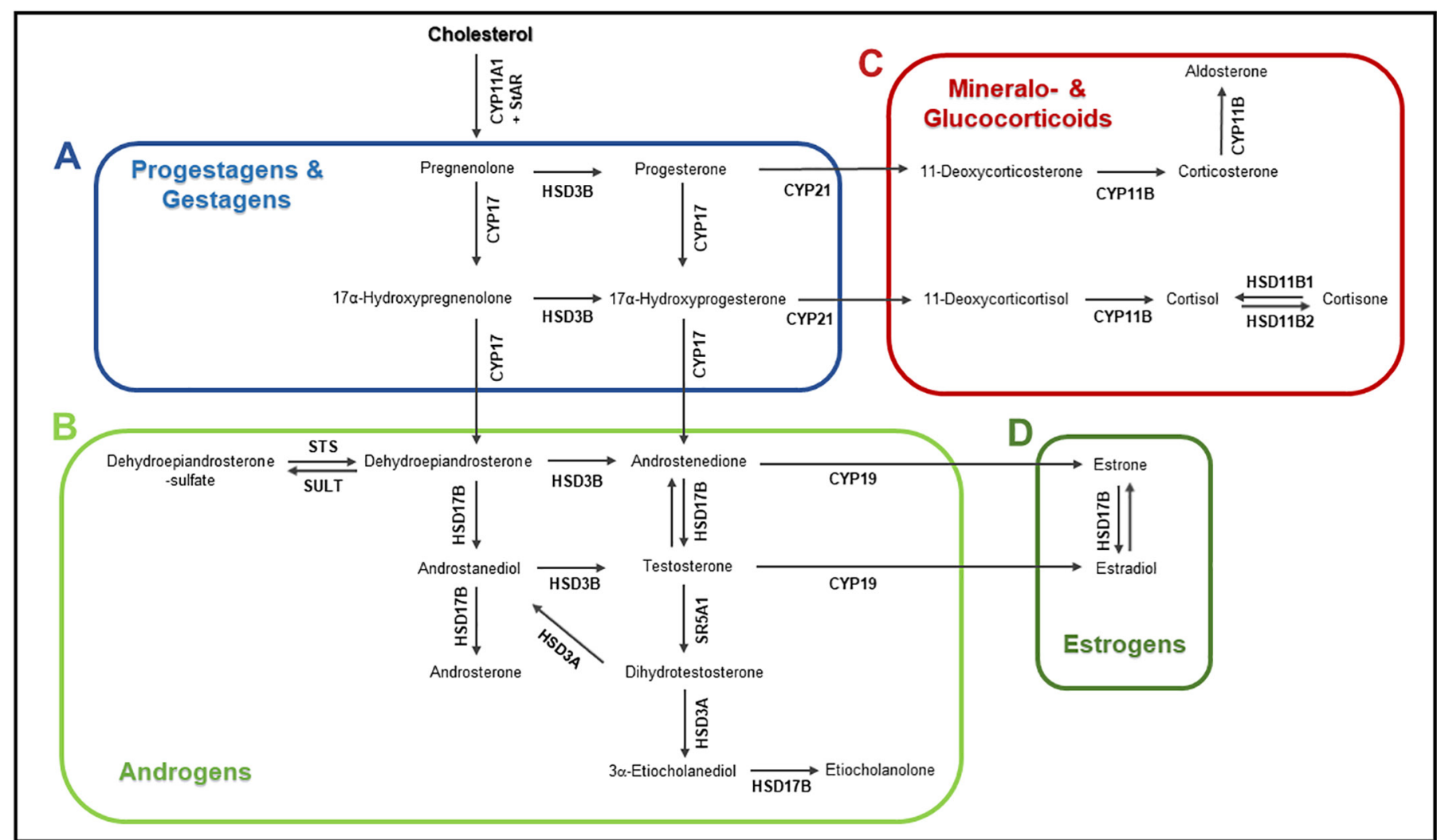

Figure 1. Biosynthetic pathway for steroid hormones. Biosynthetic pathway for (A) progestagens and gestagens, (B) mineralo- and glucocorticoids, (C) androgens, and (D) estrogens. Enzymes involved in the pathway are shown next to the arrows in bold [the figure is based on data in Figure 1 of MacKenzie et al. (2008)]. CYP11A1 = cholesterol monooxygenase; CYP11B = aldosterone synthase; CYP17 $=$ steroid- $17 \alpha-$

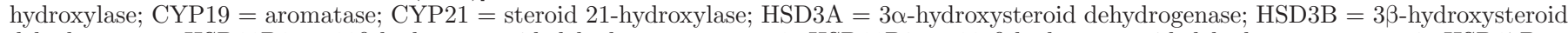
dehydrogenase; HSD11B1 = 113-hydroxysteroid dehydrogenase type 1; HSD11B2 = 11 -hydroxysteroid dehydrogenase type 2; HSD17B = $17 \beta$-hydroxysteroid dehydrogenase type $12 ;$ SR 5 A1 $=$ steroid- $5 \alpha$-reductase; StAR $=$ steroidogenic acute regulatory protein; STS $=$ steroid sulfatase; SULT $=$ sulfotransferase.

mRNA in subcutaneous and visceral AT together with increased $S T A R$ mRNA abundance in both AT depots after calving indicate bovine AT plays a role in steroid metabolism but not de novo steroid synthesis, and depends on the uptake of performed steroid precursors (Alizadeh et al., 2016a). Cholesterol reaching the inner mitochondrial membrane can alternatively be metabolized to oxysterols instead of pregnenolone. The de novo synthesis of oxysterols in adipocytes was suggested to protect adipocytes against intracellular cholesterol overload and the formation of new fat cells ( $\mathrm{Li}$ et al., 2014). For dairy cows, limited information is available on endogenous steroids and most of the studies have focused mainly on progesterone during the periparturient period (Hamudikuwanda et al., 1996; Rodrigues et al., 2011). During pregnancy, progesterone is mainly accumulated in the scAT until certain concentrations are reached (Hamudikuwanda et al., 1996). The release of progesterone from AT into circulation has been demonstrated following restrictive feeding of dairy cows (Ferraretto et al., 2014). Decreased fertility during the PP period in dairy cows could be associated with increased lipolysis and thus increased release of steroids such as progesterone from AT into the circulation (Hatler et al. 2003; Rodrigues et al., 2011). The release of steroids into the circulation could interfere with the hypothalamus-pituitary-axis and lead to impaired fertility or embryonic development. Compared with gestagens, estrogen concentrations in AT are lesser in cyclic dairy cows (estrone: $13-20 \mathrm{pg} / \mathrm{g}$, estradiol-17ß: 16-23 pg/g; Tsujioka et al., 1992). Plasma estrogens were shown to interact with the leptin system in prepubertal dairy heifers, regulating the abundance of the leptin receptor in some estrogen-responsive tissues but without effect on leptin synthesis (Thorn et al., 2008). Coupled to long-chain FA, estrogens can accumulate in tissues for prolonged periods and likely serve as storage that is directly hydrolyzed to AT (Xu et al., 2002). In humans, androgens exert important effects on AT biology, including fat mass expansion and distribution, 
insulin signaling, as well as lipid metabolism (Schiffer et al., 2019). In addition to affecting insulin signaling, androgens can also trigger lipolysis, increasing FA in the circulation (Rojas et al., 2014). Androgens serve as precursors for estrogens depending on the enzyme aromatase (CYP19), which in humans is found primarily in the ovaries but also in AT (Perel and Killinger, 1979). In dairy cows, the mRNA of CYP19 was neither detectable in scAT nor in retroperitoneal AT on d 42 $\mathrm{AP}$ and d 1, 21, and $100 \mathrm{PP}$ (Alizahdeh et al., 2016b). However, the mRNA abundance of HSD17B12, which catalyzes the conversion of estrone to estradiol-17 $\beta$ was detected in both AT depots and was greatest on d 42 $\mathrm{AP}$ with decreasing values after calving (Alizadeh et al., 2016b). Moreover, HSD17B12 mRNA abundance in scAT before calving was greater in over-conditioned cows compared with cows with normal BCS, suggesting local conversion of estradiol in cows with greater fat depots before parturition (Schuh et al., 2022). However, the role of androgens and its metabolism in AT of dairy cows is limited.

In peripheral tissues, glucocorticoids exert their catabolic effects by stimulating the release of glucose and FA as well as promoting protein breakdown (Tronche et al., 1998; Rose et al., 2010). In addition, glucocorticoids promote adipogenesis by differentiating preadipocytes into mature adipocytes (Tomlinson et al., 2007) and play a role in inflammatory processes (Coutinho and Chapman, 2011). The enzyme 11beta-hydroxysteroid dehydrogenase (HSD11B) locally regulates glucocorticoid activity (Chapman et al., 1997) by either activating cortisone to cortisol via isoform 1 (HSD11B1) or inactivating cortisol to cortisone via isoform 2 (HSD11B2). In various AT depots of early postpartum lactating dairy cows, the enzyme HSD11B1 was detected semiquantitatively by western blotting and immunohistochemistry based on an in-house developed antiserum against HSD11B1, together with an enzyme activity assay for HSD11B1 (Friedauer et al., 2015). Both the glucocorticoid receptor and the enzyme HSD11B1 were localized in mature adipocytes and cells belonging to the stromal vascular fraction within different subcutaneous and visceral AT (Friedauer et al., 2015). Based on the localization of the glucocorticoid receptor in already differentiated mature adipocytes, it has been suggested that glucocorticoids promote other effects than differentiation in bovine AT (Friedauer et al., 2015). Although, glucocorticoids have been implicated in inflammatory processes (Coutinho and Chapman, 2011), neither the glucocorticoid receptor nor the enzyme HSD11B1 was associated with the mRNA abundance of the pro-inflammatory cytokines IL6 and TNF measured in the same study by Saremi et al. (2014). The importance of AT in glucocorticoid metabolism has been demonstrated in studies of obese individuals, with increased cortisol levels in abdominal AT due to increased HSD11B1 activity (Lee et al., 2011). However, in dairy cows, information on endogenous steroids is limited to a few hormones; regarding peripartum lipolysis, data are mainly available on progesterone. Albeit the role of AT in steroid hormone metabolism in dairy cows is largely unknown, great progress has to be anticipated in view of clarifying the role of the complex mechanisms being involved in the interaction of steroid metabolism and lipid adipokines in general, based on the rapid development of targeted lipidomics.

\section{CONCLUSIONS}

In addition to energy storage, AT is recognized for its ability to secrete signaling molecules collectively termed adipokines. The adipokines play important roles in the communication between cells within the AT in an autocrine or paracrine manner and are also involved in the endocrine crosstalk with other tissues such as liver and skeletal muscle, influencing many different systems and metabolic processes in the body. In this review, we summarized the current literature regarding several selected proteinaceous adipokines with potentially important roles in dairy cows, in particular during the transition from late gestation to early lactation. Adipose tissue also releases lipid adipokines, of which endocannabinoids and steroids were in the focus of this review. The knowledge about the role of AT in the metabolism of these compounds and the systemic relevance is only in its infancy. However, in contrast to protein adipokines, whose analysis is often impeded by the lack of suitable and validated assays, and thus limited to mRNA data, lipid adipokines are expected to be better accessible, in particular when considering the rapid development of targeted lipidomics approaches. However, due to sources other than AT for both protein and lipid adipokines, interpretation of systemic changes remains challenging.

\section{ACKNOWLEDGMENTS}

This study received no external funding. The authors have not stated any conflicts of interest.

\section{REFERENCES}

Abd Eldaim, M. A., A. Kamikawa, M. M. Soliman, M. M. Ahmed, Y. Okamatsu-Ogura, A. Terao, T. Miyamoto, and K. Kimura. 2010. Retinol binding protein 4 in dairy cows: Its presence in colostrum and alteration in plasma during fasting, inflammation, and the peripartum period. J. Dairy Res. 77:27-32. https://doi.org/10.1017/ S0022029909990276. 
Accorsi, P. A., N. Govoni, R. Gaiani, C. Pezzi, E. Seren, and C. Tamanini. 2005. Leptin, GH, PRL, insulin and metabolic parameters throughout the dry period and lactation in dairy cows. Reprod. Domest. Anim. 40:217-223. https://doi.org/10.1111/j.1439-0531 2005.00581.x.

Adewuyi, A. A., E. Gruys, and F. J. C. M. van Eerdenburg. 2005. Non-esterified fatty acids (NEFA) in dairy cattle. A review. Vet. Q. 27:117-126. https://doi.org/10.1080/01652176.2005.9695192.

Ahima, R. S. 2006. Adipose tissue as an endocrine organ. Obesity (Silver Spring) 14(Suppl 5):242S-249S. https://doi.org/10.1038/ oby. 2006.317.

Alhussien, M. N., and A. K. Dang. 2020. Interaction between stress hormones and phagocytic cells and its effect on the health status of dairy cows: A review. Vet. World 13:1837-1848. https://doi.org/ 10.14202/vetworld.2020.1837-1848.

Alizadeh, A., H. Sadri, J. Rehage, S. Dänicke, and H. Sauerwein. 2016a. Expression of genes involved in the initial steps of steroidogenesis in adipose tissue depots of dairy cows during the dry period and early lactation. J. Dairy Sci. 99(E-Suppl.):1149. (Abstr.)

Alizadeh, A., H. Sadri, J. Rehage, S. Dänicke, and H. Sauerwein. 2016b. mRNA abundance of steroid hormone metabolizing enzymes (17ß-HSD isoforms and CYP19) in adipose tissue of dairy cows during the periparturient period. J Dairy Sci. 99(E-Suppl.):1088. (Abstr.)

Allen, M. S., B. J. Bradford, and K. J. Harvatine. 2005. The cow as a model to study food intake regulation. Annu. Rev. Nutr. 25:523547. https://doi.org/10.1146/annurev.nutr.25.050304.092704.

Aydin, S. 2013. Presence of adropin, nesfatin-1, apelin-12, ghrelins and salusins peptides in the milk, cheese whey and plasma of dairy cows. Peptides 43:83-87. https://doi.org/10.1016/j.peptides.2013 .02 .014 .

Badman, M. K., P. Pissios, A. R. Kennedy, G. Koukos, J. S. Flier, and E. Maratos-Flier. 2007. Hepatic fibroblast growth factor 21 is regulated by PPAR and is a key mediator of hepatic lipid metabolism in ketotic states. Cell Metab. 5:426-437. https://doi.org/10.1016/ j.cmet.2007.05.002.

Bélanger, C., V. Luu-The, P. Dupont, and A. Tchernof. 2002. Adipose tissue intracrinology: Potential importance of local androgen/estrogen metabolism in the regulation of adiposity. Horm. Metab. Res. 34:737-745. https://doi.org/10.1055/s-2002-38265.

Bell, A. W. 1995. Regulation of organic nutrient metabolism during transition from late pregnancy to early lactation. J. Anim. Sci. 73:2804-2819. https://doi.org/10.2527/1995.7392804x.

Bell, A. W., and D. E. Bauman. 1997. Adaptations of glucose metabolism during pregnancy and lactation. J. Mammary Gland Biol. Neoplasia 2:265-278. https://doi.org/10.1023/A:1026336505343.

Benomar, Y., A. Gertler, P. De Lacy, D. Crépin, H. Ould Hamouda, L. Riffault, and M. Taouis. 2013. Central resistin overexposure induces insulin resistance through Toll-like receptor 4. Diabetes 62:102-114. https://doi.org/10.2337/db12-0237.

Bernabucci, U., B. Ronchi, N. Lacetera, and A. Nardone. 2005. Influence of body condition score on relationships between metabolic status and oxidative stress in periparturient dairy cows. J. Dairy Sci. 88:2017-2026. https://doi.org/10.3168/jds.S0022 $-0302(05) 72878-2$.

Bernard, A., J. Gao-Li, C. A. Franco, T. Bouceba, A. Huet, and Z. Li. 2009. Laminin receptor involvement in the anti-angiogenic activity of pigment epithelium-derived factor. J. Biol. Chem. 284:1048010490. https://doi.org/10.1074/jbc.M809259200.

Berndt, J., N. Klöting, S. Kralisch, P. Kovacs, M. Fasshauer, M. R. Schön, M. Stumvoll, and M. Blüher. 2005. Plasma visfatin concentrations and fat depot-specific mRNA expression in humans. Diabetes 54:2911-2916. https://doi.org/10.2337/diabetes.54.10.2911.

Berni, R., M. Stoppini, M. C. Zapponi, M. L. Meloni, H. L. Monaco, and G. Zanotti. 1990. The bovine plasma retinol-binding protein amino-acid-sequence, interaction with transthyretin, crystallization and preliminary-X-ray data. Eur. J. Biochem. 192:507-513. https://doi.org/10.1111/j.1432-1033.1990.tb19254.x.

Block, S. S., W. R. Butler, R. A. Ehrhardt, A. W. Bell, M. E. van Amburgh, and Y. R. Boisclair. 2001. Decreased concentration of plasma leptin in periparturient dairy cows is caused by negative energy balance. J. Endocrinol. 171:339-348. https://doi.org/10 .1677 /joe.0.1710339.

Borg, M. L., Z. B. Andrews, E. J. Duh, R. Zechner, P. J. Meikle, and M. J. Watt. 2011. Pigment epithelium-derived factor regulates lipid metabolism via adipose triglyceride lipase. Diabetes 60:14581466. https://doi.org/10.2337/db10-0845.

Bouck, N. 2002. PEDF: Anti-angiogenic guardian of ocular function. Trends Mol. Med. 8:330-334. https://doi.org/10.1016/S1471 -4914(02)02362-6.

Boutari, C., N. Perakakis, and C. S. Mantzoros. 2018. Association of adipokines with development and progression of nonalcoholic fatty liver disease. Endocrinol. Metab. (Seoul) 33:33-43. https:// doi.org/10.3803/EnM.2018.33.1.33.

Bradford, B. J., and T. H. Swartz. 2020. Review: Following the smoke signals: Inflammatory signaling in metabolic homeostasis and homeorhesis in dairy cattle. Animal 14(S1):s144-s154. https://doi .org/10.1017/S1751731119003203.

Broch, M., R. Ramírez, M. T. Auguet, M. J. Alcaide, C. Aguilar, A. Garcia-España, and C. Richart. 2010. Macrophages are novel sites of expression and regulation of retinol binding protein-4 (RBP4). Physiol. Res. 59:299-303. https://doi.org/10.33549/physiolres .931714 .

Capurso, C., and A. Capurso. 2012. From excess adiposity to insulin resistance: The role of free fatty acids. Vascul. Pharmacol. 57:9197. https://doi.org/10.1016/j.vph.2012.05.003.

Ceciliani, F., J. J. Ceron, D. Eckersall, and H. Sauerwein. 2012. Acute phase proteins in ruminants. J. Proteomics 75:4207-4231. https:// doi.org/10.1016/j.jprot.2012.04.004.

Chapman, K. E., Y. V. Kotelevtsev, P. M. Jamieson, L. J. Williams, J. J. Mullins, and J. R. Seckl. 1997. Tissue-specific modulation of glucocorticoid action by the 11 beta-hydroxysteroid dehydrogenases. Biochem. Soc. Trans. 25:583-587. https://doi.org/10.1042/ bst0250583.

Chilliard, Y., M. Bonnet, C. Delavaud, Y. Faulconnier, C. Leroux, J. Djiane, and F. Bocquier. 2001. Leptin in ruminants. Gene expression in adipose tissue and mammary gland, and regulation of plasma concentration. Domest. Anim. Endocrinol. 21:271-295. https://doi.org/10.1016/S0739-7240(01)00124-2.

Christiansen, T., B. Richelsen, and J. M. Bruun. 2005. Monocyte chemoattractant protein- 1 is produced in isolated adipocytes, associated with adiposity and reduced after weight loss in morbid obese subjects. Int. J. Obes. (Lond) 29:146-150. https://doi.org/ 10.1038/sj.ijo.0802839.

Chung, C., J. A. Doll, A. K. Gattu, C. Shugrue, M. Cornwell, P. Fitchev, and S. E. Crawford. 2008. Anti-angiogenic pigment epithelium-derived factor regulates hepatocyte triglyceride content through adipose triglyceride lipase (ATGL). J. Hepatol. 48:471478. https://doi.org/10.1016/j.jhep.2007.10.012.

Coelho, M., T. Oliveira, and R. Fernandes. 2013. Biochemistry of adipose tissue: An endocrine organ. Arch. Med. Sci. 9:191-200. https: //doi.org/10.5114/aoms.2013.33181.

Contreras, G. A., and L. M. Sordillo. 2011. Lipid mobilization and inflammatory responses during the transition period of dairy cows. Comp Immunol Microbiol Infect Dis. 34:281-289.

Contreras, G. A., E. Kabara, J. Brester, L. Neuder, and M. Kiupel. 2015. Macrophage infiltration in the omental and subcutaneous adipose tissues of dairy cows with displaced abomasum. J. Dairy Sci. 98:6176-6187. https://doi.org/10.3168/jds.2015-9370.

Contreras, G. A., C. Strieder-Barboza, and J. De Koster. 2018. Modulating adipose tissue lipolysis and remodeling to improve immune function during the transition period and early lactation of dairy cows. J. Dairy Sci. 101:2737-2752. https://doi.org/10.3168/jds 2017-13340

Contreras, G. A., C. Strieder-Barboza, and W. Raphael. 2017. Adipose tissue lipolysis and remodeling during the transition period of dairy cows. J. Anim. Sci. Biotechnol. 8:41. https://doi.org/10 $.1186 / \mathrm{s} 40104-017-0174-4$.

Coutinho, A. E., and K. E. Chapman. 2011. The anti-inflammatory and immunosuppressive effects of glucocorticoids, recent developments and mechanistic insights. Mol. Cell. Endocrinol. 335:2-13. https://doi.org/10.1016/j.mce.2010.04.005. 
Crowe, S., L. E. Wu, C. Economou, S. M. Turpin, M. Matzaris, K. L. Hoehn, A. L. Hevener, D. E. James, E. J. Duh, and M. J. Watt. 2009. Pigment epithelium-derived factor contributes to insulin resistance in obesity. Cell Metab. 10:40-47. https://doi.org/10.1016/ j.cmet.2009.06.001

Dalla Valle, L., V. Toffolo, A. Nardi, C. Fiore, P. Bernante, R. Di Liddo, P. P. Parnigotto, and L. Colombo. 2006. Tissue-specific transcriptional initiation and activity of steroid sulfatase complementing dehydroepiandrosterone sulfate uptake and intracrine steroid activations in human adipose tissue. J. Endocrinol. 190:129-139. https://doi.org/10.1677/joe.1.06811.

Daquinag, A. C., Y. Zhang, F. Amaya-Manzanares, P. J. Simmons, and M. G. Kolonin. 2011. An isoform of decorin is a resistin receptor on the surface of adipose progenitor cells. Cell Stem Cell 9:74-86. https://doi.org/10.1016/j.stem.2011.05.017.

De Falco, M., L. De Luca, N. Onori, I. Cavalotti, F. Artigiano, V. Esposito, B. De Luca, V. Laforgia, A. M. Groeger, and A. De Luca. 2002. Apelin expression in normal human tissues. In Vivo $16: 333-336$.

De Jager, N., N. J. Hudson, A. Reverter, R. Barnard, L. M. Cafe, P. L. Greenwood, and B. P. Dalrymple. 2013. Gene expression phenotypes for lipid metabolism and intramuscular fat in skeletal muscle of cattle. J. Anim. Sci. 91:1112-1128. https://doi.org/10 .2527 /jas.2012-5409.

De Koster, J., R. K. Nelli, C. Strieder-Barboza, J. de Souza, A. L. Lock, and G. A. Contreras. 2018a. The contribution of hormone sensitive lipase to adipose tissue lipolysis and its regulation by insulin in periparturient dairy cows. Sci. Rep. 8:13378. https://doi .org/10.1038/s41598-018-31582-4.

De Koster, J., C. Strieder-Barboza, J. de Souza, A. L. Lock, and G. A. Contreras. 2018b. Short communication: Effects of body fat mobilization on macrophage infiltration in adipose tissue of early lactation dairy cows. J. Dairy Sci. 101:7608-7613. https://doi.org/ 10.3168 /jds.2017-14318.

De Koster, J., C. Urh, M. Hostens, W. Van den Broeck, H. Sauerwein, and G. Opsomer. 2017. Relationship between serum adiponectin concentration, body condition score, and peripheral tissue insulin response of dairy cows during the dry period. Domest. Anim. Endocrinol. 59:100-104. https://doi.org/10.1016/j.domaniend.2016 .12.004.

De Koster, J. D., and G. Opsomer. 2013. Insulin resistance in dairy cows. Vet. Clin. North Am. Food Anim. Pract. 29:299-322. https: //doi.org/10.1016/j.cvfa.2013.04.002.

De Petrocellis, L., and V. Di Marzo. 2009. An introduction to the endocannabinoid system: From the early to the latest concepts. Best Pract. Res. Clin. Endocrinol. Metab. 23:1-15. https://doi.org/10 .1016/j.beem.2008.10.013.

Delavaud, C., F. Bocquier, Y. Chilliard, D. H. Keisler, A. Gertler, and G. Kann. 2000. Plasma leptin determination in ruminants: Effect of nutritional status and body fatness on plasma leptin concentration assessed by a specific RIA in sheep. J. Endocrinol. 165:519526. https://doi.org/10.1677/joe.0.1650519.

Depreester, E., J. De Koster, M. Van Poucke, M. Hostens, W. Van den Broeck, L. Peelman, G. A. Contreras, and G. Opsomer. 2018. Influence of adipocyte size and adipose depot on the number of adipose tissue macrophages and the expression of adipokines in dairy cows at the end of pregnancy. J. Dairy Sci. 101:6542-6555. https://doi.org/10.3168/jds.2017-13777.

Deshmane, S. L., S. Kremlev, S. Amini, and B. E. Sawaya. 2009. Monocyte chemoattractant protein-1 (MCP-1): An overview. J. Interferon Cytokine Res. 29:313-326. https://doi.org/10.1089/jir .2008.0027.

Deslypere, J. P., L. Verdonck, and A. Vermeulen. 1985. Fat tissue: A steroid reservoir and site of steroid metabolism. J. Clin. Endocrinol. Metab. 61:564-570. https://doi.org/10.1210/jcem-61-3-564.

Diamanti-Kandarakis, E. 2007. Role of obesity and adiposity in polycystic ovary syndrome. Int. J. Obes. (Lond) 31(Suppl 2):S8-S13. https://doi.org/10.1038/sj.ijo.0803730.

Dirandeh, E., M. Ghorbanalinia, A. Rezaei-Roodbari, and M. G. Colazo. 2020. Relationship between body condition score loss and mRNA of genes related to fatty acid metabolism and the endocan- nabinoid system in adipose tissue of periparturient cows. Animal 14:1724-1732. https://doi.org/10.1017/S1751731120000476.

Douglas, G. N., J. Rehage, A. D. Beaulieu, A. O. Bahaa, and J. K. Drackley. 2007. Prepartum nutrition alters fatty acid composition in plasma, adipose tissue, and liver lipids of periparturient dairy cows. J. Dairy Sci. 90:2941-2959. https://doi.org/10.3168/jds.2006 -225 .

Drackley, J. K. 1999. Biology of dairy cows during the transition period: The final frontier? J. Dairy Sci. 82:2259-2273. https://doi .org/10.3168/jds.S0022-0302(99)75474-3.

Drackley, J. K. H. M. Dann, N. Douglas, N. A. J. Guretzky, N. B. Litherland, J. P. Underwood, and J. J. Loor. 2005. Physiological and pathological adaptations in dairy cows that may increase susceptibility to periparturient diseases and disorders. Ital. J. Anim. Sci. 4:323-344. https://doi.org/10.4081/ijas.2005.323.

Dray, C., C. Knauf, D. Daviaud, A. Waget, J. Boucher, M. Buléon, P. D. Cani, C. Attané, C. Guigné, C. Carpéné, R. Burcelin, I. Castan-Laurell, and P. Valet. 2008. Apelin stimulates glucose utilization in normal and obese insulin-resistant mice. Cell Metab. 8:437-445. https://doi.org/10.1016/j.cmet.2008.10.003.

Ehrhardt, R. A., A. Foskolos, S. L. Giesy, S. R. Wesolowski, C. S. Krumm, W. R. Butler, S. M. Quirk, M. R. Waldron, and Y. R. Boisclair. 2016. Increased plasma leptin attenuates adaptive metabolism in early lactating dairy cows. J. Endocrinol. 229:145-157. https://doi.org/10.1530/JOE-16-0031.

Ehrhardt, R. A., R. M. Slepetis, J. Siegal-Willott, M. E. van Amburgh, A. W. Bell, and Y. R. Boisclair. 2000. Development of a specific radioimmunoassay to measure physiological changes of circulating leptin in cattle and sheep. J. Endocrinol. 166:519-528. https://doi.org/10.1677/joe.0.1660519.

Elis, S., S. Coyral-Castel, S. Freret, J. Cognie, A. Desmarchais, A. Fatet, C. Rame, E. Briant, V. Maillard, and J. Dupont. 2013. Expression of adipokine and lipid metabolism genes in adipose tissue of dairy cows differing in a female fertility quantitative trait locus. J. Dairy Sci. 96:7591-7602. https://doi.org/10.3168/jds.2013-6615.

Elis, S., A. Desmarchais, S. Freret, V. Maillard, V. Labas, J. Cognie, E. Briant, C. Hivelin, J. Dupont, and S. Uzbekova. 2016. Effect of a long-chain n-3 polyunsaturated fatty acid enriched diet on adipose tissue lipid profiles and gene expression in Holstein dairy cows. J. Dairy Sci. 99:10109-10127. https://doi.org/10.3168/jds 2016-11052.

Estienne, A., A. Bongrani, M. Reverchon, C. Ramé, P.-H. Ducluzeau, P. Froment, and J. Dupont. 2019. Involvement of novel adipokines, chemerin, visfatin, resistin and apelin in reproductive functions in normal and pathological conditions in humans and animal models. Int. J. Mol. Sci. 20:4431. https://doi.org/10.3390/ijms20184431.

Fadden, A. N., and G. Bobe. 2016. Serum visfatin is a predictive indicator of retained placenta and other diseases in dairy cows. J. Vet. Sci. Med. Diagn. 5:1. https://doi.org/10.4172/2325-9590.1000188.

Famulla, S., D. Lamers, S. Hartwig, W. Passlack, A. Horrighs, A. Cramer, S. Lehr, H. Sell, and J. Eckel. 2011. Pigment epitheliumderived factor (PEDF) is one of the most abundant proteins secreted by human adipocytes and induces insulin resistance and inflammatory signaling in muscle and fat cells. Int. J. Obes. (Lond) 35:762-772. https://doi.org/10.1038/ijo.2010.212.

Ferraretto, L. F., H. Gencoglu, K. S. Hackbart, A. B. Nascimento, F. Dalla Costa, R. W. Bender, J. N. Guenther, R. D. Shaver, and M. C. Wiltbank. 2014. Effect of feed restriction on reproductive and metabolic hormones in dairy cows. J. Dairy Sci. 97:754-763. https: //doi.org/10.3168/jds.2013-6925.

Fisher, F. M., and E. Maratos-Flier. 2016. Understanding the physiology of FGF21. Annu. Rev. Physiol. 78:223-241. https://doi.org/10 .1146/annurev-physiol-021115-105339.

Flodgren, E., B. Olde, S. Meidute-Abaraviciene, M. S. Winzell, B. Ahrén, and A. Salehi. 2007. GPR40 is expressed in glucagon producing cells and affects glucagon secretion. Biochem. Biophys. Res. Commun. 354:240-245. https://doi.org/10.1016/j.bbrc.2006 .12.193.

Fried, S. K., D. A. Bunkin, and A. S. Greenberg. 1998. Omental and subcutaneous adipose tissues of obese subjects release interleukin-6: Depot difference and regulation by glucocorticoid. J. Clin. 
Endocrinol. Metab. 83:847-850. https://doi.org/10.1210/jc.83.3 .847 .

Friedauer, K., S. Dänicke, K. Schulz, H. Sauerwein, and S. Häussler. 2015. Detection of 11 beta-hydroxysteroid dehydrogenase type 1, the glucocorticoid and mineralocorticoid receptor in various adipose tissue depots of dairy cows supplemented with conjugated linoleic acids. J. Anim. Physiol. Anim. Nutr. (Berl.) 99:950-961. https://doi.org/10.1111/jpn.12268.

Friedman, J. M., and J. L. Halaas. 1998. Leptin and the regulation of body weight in mammals. Nature 395:763-770. https://doi.org/10 $.1038 / 27376$

Friedrichs, P., B. Saremi, S. Winand, J. Rehage, S. Dänicke, H. Sauerwein, and M. Mielenz. 2014. Energy and metabolic sensing G protein-coupled receptors during lactation-induced changes in energy balance. Domest. Anim. Endocrinol. 48:33-41. https://doi .org/10.1016/j.domaniend.2014.01.005.

Frühbeck, G., L. Méndez-Giménez, J. A. Fernández-Formoso, S. Fernández, and A. Rodríguez. 2014. Regulation of adipocyte lipolysis. Nutr. Res. Rev. 27:63-93. https://doi.org/10.1017/ S095442241400002X.

Fu, Y., N. Luo, R. L. Klein, and W. T. Garvey. 2005. Adiponectin promotes adipocyte differentiation, insulin sensitivity, and lipid accumulation. J. Lipid Res. 46:1369-1379. https://doi.org/10.1194/ jlr.M400373-JLR200.

Fu, Y. Y., K. L. Chen, H. X. Li, and G. H. Zhou. 2016. The adipokine Chemerin induces lipolysis and adipogenesis in bovine intramuscular adipocytes. Mol. Cell. Biochem. 418:39-48. https://doi.org/10 $.1007 / \mathrm{s} 11010-016-2731-0$.

Fukuhara, A., M. Matsuda, M. Nishizawa, K. Segawa, M. Tanaka, K. Kishimoto, Y. Matsuki, M. Murakami, T. Ichisaka, H. Murakami, E. Watanabe, T. Takagi, M. Akiyoshi, T. Ohtsubo, S. Kihara, S. Yamashita, M. Makishima, T. Funahashi, S. Yamanaka, R. Hiramatsu, Y. Matsuzawa, and I. Shimomura. 2005. Visfatin: A protein secreted by visceral fat that mimics the effects of insulin. Obstet. Gynecol. Surv. 60:523-524. https://doi.org/10.1097/01 .ogx.0000172388.75302.e6.

Funcke, J.-B., and P. E. Scherer. 2019. Beyond adiponectin and leptin: Adipose tissue-derived mediators of inter-organ communication. J. Lipid Res. 60:1648-1697. https://doi.org/10.1194/jlr.R094060.

Garbers, C., H. M. Hermanns, F. Schaper, G. Muller-Newen, J. Grotzinger, S. Rose-John, and J. Scheller. 2012. Plasticity and crosstalk of interleukin 6-type cytokines. Cytokine Growth Factor Rev. 23:85-97. https://doi.org/10.1016/j.cytogfr.2012.04.001.

Gerhardt, C. C., I. A. Romero, R. Cancello, L. Camoin, and A. D. Strosberg. 2001. Chemokines control fat accumulation and leptin secretion by cultured human adipocytes. Mol. Cell. Endocrinol. 175:81-92. https://doi.org/10.1016/S0303-7207(01)00394-X.

Giesy, S. L., B. Yoon, W. B. Currie, J. W. Kim, and Y. R. Boisclair. 2012. Adiponectin deficit during the precarious glucose economy of early lactation in dairy cows. Endocrinology 153:5834-5844. https: //doi.org/10.1210/en.2012-1765.

Graham, T. E., Q. Yang, M. Blüher, A. Hammarstedt, T. P. Ciaraldi, R. R. Henry, C. J. Wason, A. Oberbach, P. A. Jansson, U. Smith, and B. B. Kahn. 2006. Retinol-binding protein 4 and insulin resistance in lean, obese, and diabetic subjects. N. Engl. J. Med. 354:2552-2563. https://doi.org/10.1056/NEJMoa054862.

Grummer, R. R., S. J. Bertics, D. W. Lacount, J. A. Snow, M. R. Dentine, and R. H. Stauffacher. 1990. Estrogen induction of fatty liver in dairy cattle. J. Dairy Sci. 73:1537-1543. https://doi.org/10 .3168/jds.S0022-0302(90)78822-4.

Habata, Y., R. Fujii, M. Hosoya, S. Fukusumi, Y. Kawamata, S. Hinuma, C. Kitada, N. Nishizawa, S. Murosaki, T. Kurokawa, H. Onda, K. Tatemoto, and M. Fujino. 1999. Apelin, the natural ligand of the orphan receptor APJ, is abundantly secreted in the colostrum. Biochim. Biophys. Acta 1452:25-35. https://doi.org/10.1016/ S0167-4889(99)00114-7.

Hamudikuwanda, H., G. Gallo, E. Block, and B. R. Downey. 1996. Adipose tissue progesterone concentrations in dairy cows during late pregnancy and early lactation. Anim. Reprod. Sci. 43:15-23. https://doi.org/10.1016/0378-4320(96)01468-6.
Han, M. S., A. White, R. J. Perry, J. P. Camporez, J. Hidalgo, G. I. Shulman, and R. J. Davis. 2020. Regulation of adipose tissue inflammation by interleukin 6. Proc. Natl. Acad. Sci. USA 117:27512760. https://doi.org/10.1073/pnas.1920004117.

Hara, T., D. Kashihara, A. Ichimura, I. Kimura, G. Tsujimoto, and A. Hirasawa. 2014. Role of free fatty acid receptors in the regulation of energy metabolism. Biochim. Biophys. Acta 1841:1292-1300. https://doi.org/10.1016/j.bbalip.2014.06.002.

Hara, T., I. Kimura, D. Inoue, A. Ichimura, and A. Hirasawa. 2013. Free fatty acid receptors and their role in regulation of energy metabolism. Pages 77-116 in Reviews of Physiology, Biochemistry and Pharmacology, Vol. 164. B. Nilius, S. G. Amara, R. Lill, S. Offermanns, T. Gudermann, O. H. Petersen, and R. Jahn, ed. Springer International Publishing. https://doi.org/10.1007/112 2013_13

Hatler, T. B., S. H. Hayes, L. F. Laranja da Fonseca, and W. J. Silvia. 2003. Relationship between endogenous progesterone and follicular dynamics in lactating dairy cows with ovarian follicular cysts. Biol. Reprod. 69:218-223. https://doi.org/10.1095/biolreprod.102 .012179 .

Häussler, S., C. Sacré, K. Friedauer, S. Dänicke, and H. Sauerwein. 2015. Short communication: Localization and expression of monocyte chemoattractant protein- 1 in different subcutaneous and visceral adipose tissues of early-lactating dairy cows. J. Dairy Sci. 98:6278-6283. https://doi.org/10.3168/jds.2014-9256.

Helfer, G., and Q. F. Wu. 2018. Chemerin: A multifaceted adipokine involved in metabolic disorders. J. Endocrinol. 238:R79-R94. https://doi.org/10.1530/JOE-18-0174.

Hill, A. A., W. R. Bolus, and A. H. Hasty. 2014. A decade of progress in adipose tissue macrophage biology. Immunol. Rev. 262:134-152. https://doi.org/10.1111/imr.12216.

Holland, W. L., A. C. Adams, J. T. Brozinick, H. H. Bui, Y. Miyauchi, C. M. Kusminski, S. M. Bauer, M. Wade, E. Singhal, C. C. Cheng, K. Volk, M. S. Kuo, R. Gordillo, A. Kharitonenkov, and P. E. Scherer. 2013. An FGF21-adiponectin-ceramide axis controls energy expenditure and insulin action in mice. Cell Metab. 17:790-797. https://doi.org/10.1016/j.cmet.2013.03.019.

Holst, J. P., O. P. Soldin, T. Guo, and S. J. Soldin. 2004. Steroid hormones: Relevance and measurement in the clinical laboratory. Clin. Lab. Med. 24:105-118. https://doi.org/10.1016/j.cll.2004.01 .004 .

Holtenius, K., S. Agenäs, C. Delavaud, and Y. Chilliard. 2003. Effects of Feeding intensity during the dry period. 2. Metabolic and hormonal responses. J. Dairy Sci. 86:883-891. https://doi.org/10 .3168/jds.S0022-0302(03)73671-6.

Hong, Y.-H., Y. Nishimura, D. Hishikawa, H. Tsuzuki, H. Miyahara, C. Gotoh, K.-C. Choi, D. D. Feng, C. Chen, H.-G. Lee, K. Katoh, S.-G. Roh, and S. Sasaki. 2005. Acetate and propionate short chain fatty acids stimulate adipogenesis via GPCR43. Endocrinology 146:5092-5099. https://doi.org/10.1210/en.2005-0545.

Hosoya, M., Y. Kawamata, S. Fukusumi, R. Fujii, Y. Habata, S. Hinuma, C. Kitada, S. Honda, T. Kurokawa, H. Onda, O. Nishimura, and M. Fujino. 2000. Molecular and functional characteristics of APJ. Tissue distribution of mRNA and interaction with the endogenous ligand apelin. J. Biol. Chem. 275:21061-21067. https:// doi.org/10.1074/jbc.M908417199.

Hosseini, A., H. Sauerwein, and M. Mielenz. 2010. Putative reference genes for gene expression studies in propionate and $\beta$-hydroxybutyrate treated bovine adipose tissue explants. J. Anim. Physiol. Anim. Nutr. (Berl.) 94:e178-e184. https://doi.org/ 10.1111/j.1439-0396.2010.01002.x.

Hotamisligil, G. S., N. S. Shargill, and B. M. Spiegelman. 1993. Adipose expression of tumor necrosis factor-alpha: Direct role in obesity-linked insulin resistance. Science 259:87-91. https://doi.org/ 10.1126 /science. 7678183 .

Ichimura, A., S. Hasegawa, M. Kasubuchi, and I. Kimura. 2014. Free fatty acid receptors as therapeutic targets for the treatment of diabetes. Front. Pharmacol. 5:236. https://doi.org/10.3389/fphar .2014.00236.

Inagaki, T., P. Dutchak, G. Zhao, X. Ding, L. Gautron, V. Parameswara, Y. Li, R. Goetz, M. Mohammadi, V. Esser, J. K. Elmquist, R. D. 
Gerard, S. C. Burgess, R. E. Hammer, D. J. Mangelsdorf, and S. A. Kliewer. 2007. Endocrine regulation of the fasting response by PPAR-mediated induction of fibroblast growth factor 21. Cell Metab. 5:415-425. https://doi.org/10.1016/j.cmet.2007.05.003.

Ingvartsen, K. L., and Y. R. Boisclair. 2001. Leptin and the regulation of food intake, energy homeostasis and immunity with special focus on periparturient ruminants. Domest. Anim. Endocrinol. 21:215-250. https://doi.org/10.1016/S0739-7240(02)00119-4.

Itoh, N. 2010. Hormone-like (endocrine) Fgfs: Their evolutionary history and roles in development, metabolism, and disease. Cell Tissue Res. 342:1-11. https://doi.org/10.1007/s00441-010-1024-2.

Itoh, N. 2014. FGF21 as a hepatokine, adipokine, and myokine in metabolism and diseases. Front Endocrinol. 5:107. https://doi.org/10 $.3389 /$ fendo.2014.00107.

Jäntti, S. E., M. Kivilompolo, L. Ohrnberg, K. H. Pietiläinen, H. Nygren, M. Orešič, and T. Hyötyläinen. 2014. Quantitative profiling of bile acids in blood, adipose tissue, intestine, and gall bladder samples using ultra high performance liquid chromatographytandem mass spectrometry. Anal. Bioanal. Chem. 406:7799-7815. https://doi.org/10.1007/s00216-014-8230-9.

Jasinski-Bergner, S., M. Büttner, D. Quandt, B. Seliger, and H. Kielstein. 2017. Adiponectin and its receptors are differentially expressed in human tissues and cell lines of distinct origin. Obes. Facts 10:569-583. https://doi.org/10.1159/000481732.

Kabara, E., L. M. Sordillo, S. Holcombe, and G. A. Contreras. 2014. Adiponectin links adipose tissue function and monocyte inflammatory responses during bovine metabolic stress. Comp. Immunol. Microbiol. Infect. Dis. 37:49-58. https://doi.org/10.1016/j.cimid .2013 .10 .007 .

Kanda, H., S. Tateya, Y. Tamori, K. Kotani, K. Hiasa, R. Kitazawa, S. Kitazawa, H. Miyachi, S. Maeda, K. Egashira, and M. Kasuga. 2006. MCP-1 contributes to macrophage infiltration into adipose tissue, insulin resistance, and hepatic steatosis in obesity. J. Clin. Invest. 116:1494-1505. https://doi.org/10.1172/JCI26498.

Kauter, K., M. Ball, P. Kearney, R. Tellam, and J. R. McFarlane. 2000. Adrenaline, insulin and glucagon do not have acute effects on plasma leptin levels in sheep: Development and characterisation of an ovine leptin ELISA. J. Endocrinol. 166:127-135. https://doi .org/10.1677/joe.0.1660127.

Kenéz, Á., A. Kulcsár, F. Kluge, I. Benbelkacem, K. Hansen, L. Locher, U. Meyer, J. Rehage, S. Dänicke, and K. Huber. 2015. Changes of adipose tissue morphology and composition during late pregnancy and early lactation in dairy cows. PLoS One 10:e0127208. https:/ /doi.org/10.1371/journal.pone.0127208.

Kenéz, Á., L. Ruda, S. Dänicke, and K. Huber. 2019. Insulin signaling and insulin response in subcutaneous and retroperitoneal adipose tissue in Holstein cows during the periparturient period. J. Dairy Sci. 102:11718-11729. https://doi.org/10.3168/jds.2019-16873.

Kershaw, E. E., and J. S. Flier. 2004. Adipose tissue as an endocrine organ. J. Clin. Endocrinol. Metab. 89:2548-2556. https://doi.org/ 10.1210/jc.2004-0395.

Kharitonenkov, A., T. L. Shiyanova, A. Koester, A. M. Ford, R. Micanovic, E. J. Galbreath, G. E. Sandusky, L. J. Hammond, J. S. Moyers, R. A. Owens, J. Gromada, J. T. Brozinick, E. D. Hawkins, V. J. Wroblewski, D. S. Li, F. Mehrbod, S. R. Jaskunas, and A. B. Shanafelt. 2005. FGF-21 as a novel metabolic regulator. J. Clin. Invest. 115:1627-1635. https://doi.org/10.1172/JCI23606.

Kiernan, K., and N. J. MacIver. 2021. The role of the adipokine leptin in immune cell function in health and disease. Front. Immunol. 11:622468. https://doi.org/10.3389/fimmu.2020.622468.

Kilicarslan, M., B. A. de Weijer, K. Simonyté Sjodin, P. Aryal, K. W. ter Horst, H. Cakir, J. A. Romijn, M. T. Ackermans, I. M. Janssen, F. J. Berends, A. W. van de Laar, A. P. Houdijk, B. B. Kahn, and M. J. Serlie. 2020. RBP4 increases lipolysis in human adipocytes and is associated with increased lipolysis and hepatic insulin resistance in obese women. FASEB J. 34:6099-6110. https: //doi.org/10.1096/fj.201901979RR.

Kita, S., S. Fukuda, N. Maeda, and I. Shimomura. 2019. Native adiponectin in serum binds to mammalian cells expressing T-cadherin, but not AdipoRs or calreticulin. Elife 8:e48675. https://doi.org/10 $.7554 /$ eLife. 48675 .
Klöting, N., T. E. Graham, J. Berndt, S. Kralisch, P. Kovacs, C. J. Wason, M. Fasshauer, M. R. Schon, M. Stumvoll, M. Blüher, and B. B. Kahn. 2007. Serum retinol-binding protein is more highly expressed in visceral than in subcutaneous adipose tissue and is a marker of intra-abdominal fat mass. Cell Metab. 6:79-87. https:// doi.org/10.1016/j.cmet.2007.06.002.

Koelman, L., R. Reichmann, C. Börnhorst, M. B. Schulze, C. Weikert, R. Biemann, B. Isermann, A. Fritsche, and K. Aleksandrova. 2021. Determinants of elevated chemerin as a novel biomarker of immunometabolism: Data from a large population-based cohort. Endocr. Connect. 10:1200-1211. https://doi.org/10.1530/EC-21 $-0273$.

Kokkonen, T., J. Taponen, T. Anttila, L. Syrjälä-Qvist, C. Delavaud, Y. Chilliard, M. Tuori, and A. T. Tesfa. 2005. Effect of body fatness and glucogenic supplement on lipid and protein mobilization and plasma leptin in dairy cows. J. Dairy Sci. 88:1127-1141. https: //doi.org/10.3168/jds.S0022-0302(05)72779-X.

Kopp, C., A. Hosseini, S. P. Singh, P. Regenhard, H. KhalilvandiBehroozyar, H. Sauerwein, and M. Mielenz. 2014. Nicotinic acid increases adiponectin secretion from differentiated bovine preadipocytes through G-protein coupled receptor signaling. Int. J. Mol. Sci. 15:21401-21418. https://doi.org/10.3390/ijms151121401.

Krautbauer, S., J. Wanninger, K. Eisinger, Y. Hader, M. Beck, A. Kopp, A. Schmid, T. S. Weiss, C. Dorn, and C. Buechler. 2013. Chemerin is highly expressed in hepatocytes and is induced in non-alcoholic steatohepatitis liver. Exp. Mol. Pathol. 95:199-205. https://doi.org/10.1016/j.yexmp.2013.07.009.

Krumm, C. S., S. L. Giesy, L. S. Caixeta, J. W. Perfield 2nd, H. Sauerwein, B. L. Moore, and Y. R. Boisclair. 2019. Fibroblast growth factor-21 (FGF21) administration to early-lactating dairy cows. I. Effects on signaling and indices of insulin action. J. Dairy Sci 102:11586-11596. https://doi.org/10.3168/jds.2019-16695.

Kuhla, B. 2020. Review: Pro-inflammatory cytokines and hypothalamic inflammation: Implications for insufficient feed intake of transition dairy cows. Animal 14(S1):s65-s77. https://doi.org/10 $.1017 /$ S1751731119003124.

Kuhla, B., V. Kaever, A. Tuchscherer, and A. Kuhla. 2020. Involvement of plasma endocannabinoids and the hypothalamic endocannabinoid system in increasing feed intake after parturition of dairy cows. Neuroendocrinology 110:246-257. https://doi.org/10.1159/ 000501208.

Kuperman, Y., O. Issler, J. Vaughan, L. Bilezikjian, W. Vale, and A. Chen. 2011. Expression and regulation of corticotropin-releasing factor receptor type 2 beta in developing and mature mouse skeletal muscle. Mol. Endocrinol. 25:157-169. https://doi.org/10.1210/ me.2010-0308.

Kurowska, P., A. Barbe, M. Różycka, J. Chmielińska, J. Dupont, and A. Rak. 2018. Apelin in reproductive physiology and pathology of different species: A critical review. Int. J. Endocrinol. 2018:9170480. https://doi.org/10.1155/2018/9170480.

Kushibiki, S., K. Hodatet, H. Shingu, T. Hayashi, E. Touno, M. Shinoda, and Y. Yokomizo. 2002. Alterations in lipid metabolism induced by recombinant bovine tumor necrosis factor-alpha administration to dairy heifers. J. Anim. Sci. 80:2151-2157. https://doi .org/10.2527/2002.8082151x.

Labrie, F. 1991. Intracrinology. Mol. Cell. Endocrinol. 78:C113-C118. https://doi.org/10.1016/0303-7207(91)90116-A.

Lacetera, N., D. Scalia, U. Bernabucci, B. Ronchi, D. Pirazzi, and A. Nardone. 2005. Lymphocyte functions in overconditioned cows around parturition. J. Dairy Sci. 88:2010-2016. https://doi.org/10 .3168/jds.S0022-0302(05)72877-0.

Laeger, T., H. Sauerwein, A. Tuchscherer, O. Bellmann, C. C. Metges, and B. Kuhla. 2013. Concentrations of hormones and metabolites in cerebrospinal fluid and plasma of dairy cows during the periparturient period. J. Dairy Sci. 96:2883-2893. https://doi.org/10 $.3168 /$ jds.2012-5909.

Lee, M.-J., D.-W. Gong, B. F. Burkey, and S. K. Fried. 2011. Pathways regulated by glucocorticoids in omental and subcutaneous human adipose tissues: A microarray study. Am. J. Physiol. Endocrinol. Metab. 300:E571-E580. https://doi.org/10.1152/ajpendo .00231 .2010 
Lee, S., H.-C. Lee, Y.-W. Kwon, S. E. Lee, Y. Cho, J. Kim, S. Lee, J.Y. Kim, J. Lee, H.-M. Yang, I. Mook-Jung, K.-Y. Nam, J. Chung, M. A. Lazar, and H.-S. Kim. 2014. Adenylyl cyclase-associated protein 1 is a receptor for human resistin and mediates inflammatory actions of human monocytes. Cell Metab. 19:484-497. https:/ /doi.org/10.1016/j.cmet.2014.01.013.

Lemor, A., A. Hosseini, H. Sauerwein, and M. Mielenz. 2009. Transition period-related changes in the abundance of the mRNAs of adiponectin and its receptors, of visfatin, and of fatty acid binding receptors in adipose tissue of high-yielding dairy cows. Domest. Anim. Endocrinol. 37:37-44. https://doi.org/10.1016/j.domaniend .2009.01.004

Li, J., E. Daly, E. Campioli, M. Wabitsch, and V. Papadopoulos. 2014. De novo synthesis of steroids and oxysterols in adipocytes. J. Biol. Chem. 289:747-764. https://doi.org/10.1074/jbc.M113.534172.

Liefers, S. C., R. F. Veerkamp, M. F. W. Te Pas, Y. Chilliard, and T. van der Lende. 2005. Genetics and physiology of leptin in periparturient dairy cows. Domest. Anim. Endocrinol. 29:227-238. https: //doi.org/10.1016/j.domaniend.2005.02.009.

Lin, Z., H. Tian, K. S. Lam, S. Lin, R. C. Hoo, M. Konishi, N. Itoh, Y. Wang, S. R. Bornstein, A. Xu, and X. Li. 2013. Adiponectin mediates the metabolic effects of FGF21 on glucose homeostasis and insulin sensitivity in mice. Cell Metab. 17:779-789. https:// doi.org/10.1016/j.cmet.2013.04.005.

Lindberg, L. A., H. Sinkkonen, A. R. Pösö, A. T. Tesfa, and J. Schröder. 1999. Production of monoclonal antibodies and enzyme immunoassay to bovine retinol-binding protein and determination of retinol-binding protein serum levels and retinol concentrations in serum and liver in dairy cows before and after parturition. Res. Vet. Sci. 66:259-263. https://doi.org/10.1053/rvsc.1998.0280.

Lindholm-Perry, A. K., L. A. Kuehn, L. A. Rempel, T. P. Smith, R. A. Cushman, T. G. McDaneld, T. L. Wheeler, S. D. Shackelford, D. A. King, and H. C. Freetly. 2012. Evaluation of Bovine chemerin (RARRES2) gene variation on beef cattle production traits. Front. Genet. 3:39. https://doi.org/10.3389/fgene.2012.00039.

Liu, Y., E. Albrecht, D. Dannenberger, H. M. Hammon, C. Kuehn, H. Sauerwein, R. J. Yang, Z. H. Zhao, and S. Maak. 2019. Retinol binding protein 4 abundance in plasma and tissues is related to body fat deposition in cattle. Sci. Rep. 9:8056. https://doi.org/10 .1038/s41598-019-44509-4.

Lopreiato, V., A. Hosseini, F. Rosa, Z. Zhou, A. Alharthi, E. Trevisi, and J. J. Loor. 2018. Dietary energy level affects adipose depot mass but does not impair in vitro subcutaneous adipose tissue response to short-term insulin and tumor necrosis factor- $\alpha$ challenge in nonlactating, nonpregnant Holstein cows. J. Dairy Sci. 101:10206-10219. https://doi.org/10.3168/jds.2018-14389.

Lord, G. M., G. Matarese, J. K. Howard, R. J. Baker, S. R. Bloom, and R. I. Lechler. 1998. Leptin modulates the T-cell immune response and reverses starvation-induced immunosuppression. Nature 394:897-901. https://doi.org/10.1038/29795.

Lu, H. C., and K. Mackie. 2016. An introduction to the endogenous cannabinoid system. Biol. Psychiatry 79:516-525. https://doi.org/ 10.1016/j.biopsych.2015.07.028.

Ma, W.-Y., T.-Y. Yu, J.-N. Wei, C.-S. Hung, M.-S. Lin, Y.-J. Liao, D. Pei, C.-C. Su, K.-C. Lu, P.-H. Liu, C.-H. Lin, L.-M. Chuang, H.-L. Kao, J.-W. Lin, Y.-J. Chuang, and H.-Y. Li. 2014. Plasma apelin: A novel biomarker for predicting diabetes. Clin. Chim. Acta 435:18-23. https://doi.org/10.1016/j.cca.2014.03.030.

MacKenzie, S. M., S. S. Huda, N. Sattar, R. Fraser, J. M. C. Connell, and E. Davies. 2008. Depot-specific steroidogenic gene transcription in human adipose tissue. Clin. Endocrinol. (Oxf.) 69:848-854. https://doi.org/10.1111/j.1365-2265.2008.03262.x.

Maillard, V., P. Froment, C. Ramé, S. Uzbekova, S. Elis, and J. Dupont. 2011. Expression and effect of resistin on bovine and rat granulosa cell steroidogenesis and proliferation. Reproduction 141:467-479. https://doi.org/10.1530/REP-10-0419.

Makki, K., P. Froguel, and I. Wolowczuk. 2013. Adipose tissue in obesity-related inflammation and insulin resistance: Cells, cytokines, and chemokines. ISRN Inflamm. 2013:139239. https://doi.org/10 $.1155 / 2013 / 139239$.
Mann, S., D. V. Nydam, A. Abuelo, F. A. Leal Yepes, T. R. Overton, and J. J. Wakshlag. 2016. Insulin signaling, inflammation, and lipolysis in subcutaneous adipose tissue of transition dairy cows either overfed energy during the prepartum period or fed a controlled-energy diet. J. Dairy Sci. 99:6737-6752. https://doi.org/10 $.3168 / j d s .2016-10969$.

Mansouryar, M., H. Mirzaei-Alamouti, M. Dehghan Banadaky, H. Sauerwein, M. Mielenz, and M. O. Nielsen. 2018. Short communication: Relationship between body condition score and plasma adipokines in early-lactating Holstein dairy cows. J. Dairy Sci. 101:8552-8558. https://doi.org/10.3168/jds.2017-14122.

Martel, C. A., L. K. Mamedova, J. E. Minton, M. L. Jones, J. A. Carroll, and B. J. Bradford. 2014. Continuous low-dose infusion of tumor necrosis factor alpha in adipose tissue elevates adipose tissue interleukin 10 abundance and fails to alter metabolism in lactating dairy cows. J. Dairy Sci. 97:4897-4906. https://doi.org/ 10.3168 /jds.2013-7777.

McCracken, J. A. 1964. Progesteone in the body fat of the dairy cow. J. Endocrinol. 28:339-340. https://doi.org/10.1677/joe.0.0280339.

McNamara, J. P. 1994. Lipid-metabolism in adipose-tissue during lactation: A model of a metabolic control-system. J. Nutr. 124(8 Suppl):1383S-1391S. https://doi.org/10.1093/jn/124.suppl_8 $.1383 \mathrm{~S}$.

McNamara, J. P., and K. Huber. 2018. Metabolic and endocrine role of adipose tissue during lactation. Annu. Rev. Anim. Biosci. 6:177195. https://doi.org/10.1146/annurev-animal-030117-014720.

Meidute Abaraviciene, S., S. J. Muhammed, S. Amisten, I. Lundquist, and A. Salehi. 2013. GPR40 protein levels are crucial to the regulation of stimulated hormone secretion in pancreatic islets. Lessons from spontaneous obesity-prone and non-obese type 2 diabetes in rats. Mol. Cell. Endocrinol. 381:150-159. https://doi.org/10.1016/ j.mce.2013.07.025.

Mellouk, N., C. Rame, M. Diot, E. Briant, J. L. Touze, D. Guillaume, P. Froment, and J. Dupont. 2019. Possible involvement of the RARRES2/CMKLR1-system in metabolic and reproductive parameters in Holstein dairy cows. Reprod. Biol. Endocrinol. 17:25. https://doi.org/10.1186/s12958-019-0467-x.

Mellouk, N., C. Rame, J. L. Touzé, E. Briant, L. Ma, D. Guillaume, D. Lomet, A. Caraty, T. Ntallaris, P. Humblot, and J. Dupont. 2017. Involvement of plasma adipokines in metabolic and reproductive parameters in Holstein dairy cows fed with diets with differing energy levels. J. Dairy Sci. 100:8518-8533. https://doi.org/10.3168/ jds.2017-12657.

Mesmin, C., F. Fenaille, F. Becher, J.-C. Tabet, and E. Ezan. 2011. Identification and characterization of apelin peptides in bovine colostrum and milk by liquid chromatography-mass spectrometry. J. Proteome Res. 10:5222-5231. https://doi.org/10.1021/pr200725x.

Mielenz, M. 2017. Invited review: Nutrient-sensing receptors for free fatty acids and hydroxycarboxylic acids in farm animals. Animal 11:1008-1016. https://doi.org/10.1017/S175173111600238X.

Morrison, C. D., J. A. Daniel, B. J. Holmberg, J. Djiane, N. Raver, A. Gertler, and D. H. Keisler. 2001. Central infusion of leptin into well-fed and undernourished ewe lambs: Effects on feed intake and serum concentrations of growth hormone and luteinizing hormone. J. Endocrinol. 168:317-324. https://doi.org/10.1677/joe .0 .1680317 .

Myers, M. N., M. Zachut, J. Tam, and G. A. Contreras. 2021. A proposed modulatory role of the endocannabinoid system on adipose tissue metabolism and appetite in periparturient dairy cows. J. Anim. Sci. Biotechnol. 12:21. https://doi.org/10.1186/s40104-021 $-00549-3$.

Newell-Fugate, A. E. 2017. The role of sex steroids in white adipose tissue adipocyte function. Reproduction 153:R133-R149. https:// doi.org/10.1530/REP-16-0417.

Nogueiras, R., A. Diaz-Arteaga, S. H. Lockie, D. A. Velásquez, J. Tschop, M. López, C. C. Cadwell, C. Diéguez, and M. H. Tschöp. 2009. The endocannabinoid system: role in glucose and energy metabolism. Pharmacol. Res. 60:93-98. https://doi.org/10.1016/ j.phrs.2009.04.004.

Norvezh, F., M. Razi Jalali, M. R. Tabandeh, M. R. H. Hajikolaei, and S. Gooraninejad. 2019. Serum Apelin-36 alteration in late 
pregnancy and early lactation of dairy cows and its association with negative energy balance markers. Res. Vet. Sci. 125:285-289. https://doi.org/10.1016/j.rvsc.2019.07.012.

Notari, L., V. Baladron, J. D. Aroca-Aguilar, N. Balko, R. Heredia, C. Meyer, P. M. Notario, S. Saravanamuthu, M.-L. Nueda, F. Sanchez-Sanchez, J. Escribano, J. Laborda, and S. P. Becerra. 2006. Identification of a lipase-linked cell membrane receptor for pigment epithelium-derived factor. J. Biol. Chem. 281:38022-38037. https://doi.org/10.1074/jbc.M600353200.

O'Boyle, N., C. M. Corl, J. C. Gandy, and L. M. Sordillo. 2006. Relationship of body condition score and oxidant stress to tumor necrosis factor expression in dairy cattle. Vet. Immunol. Immunopathol. 113:297-304. https://doi.org/10.1016/j.vetimm.2006.05.013.

Olefsky, J. M., and C. K. Glass. 2010. Macrophages, inflammation, and insulin resistance. Annu. Rev. Physiol. 72:219-246. https:// doi.org/10.1146/annurev-physiol-021909-135846.

Parimisetty, A., A. C. Dorsemans, R. Awada, P. Ravanan, N. Diotel, and C. Lefebvre d'Hellencourt. 2016. Secret talk between adipose tissue and central nervous system via secreted factors - an emerging frontier in the neurodegenerative research. J. Neuroinflammation 13:67. https://doi.org/10.1186/s12974-016-0530-x.

Perduca, M., S. Nicolis, B. Mannucci, M. Galliano, and H. L. Monaco. 2018. Human plasma retinol-binding protein (RBP4) is also a fatty acid-binding protein. Biochim. Biophys. Acta Mol. Cell Biol. Lipids 1863:458-466. https://doi.org/10.1016/j.bbalip.2018.01.010.

Pereira, G., R. Bexiga, J. Chagas e Silva, E. Silva, C. Ramé, J. Dupont, Y. Guo, P. Humblot, and L. Lopes-da-Costa. 2020. Adipokines as biomarkers of postpartum subclinical endometritis in dairy cows. Reproduction 160:417-430. https://doi.org/10.1530/ REP-20-0183.

Perel, E., and D. W. Killinger. 1979. The interconversion and aromatization of androgens by human adipose tissue. J. Steroid Biochem. 10:623-627. https://doi.org/10.1016/0022-4731(79)90514-4.

Pertwee, R. G. 1997. Pharmacology of cannabinoid CB1 and CB2 receptors. Pharmacol. Ther. 74:129-180. https://doi.org/10.1016/ S0163-7258(97)82001-3.

Pertwee, R. G., and R. A. Ross. 2002. Cannabinoid receptors and their ligands. Prostaglandins Leukot. Essent. Fatty Acids 66:101-121. https://doi.org/10.1054/plef.2001.0341.

Pillai-Kastoori, L., A. R. Schutz-Geschwender, and J. A. Harford. 2020. A systematic approach to quantitative Western blot analysis. Anal. Biochem. 593:113608. https://doi.org/10.1016/j.ab.2020 .113608 .

Rak, A., N. Mellouk, P. Froment, and J. Dupont. 2017. Adiponectin and resistin: Potential metabolic signals affecting hypothalamopituitary gonadal axis in females and males of different species. Reproduction 153:R215-R226. https://doi.org/10.1530/REP-17 -0002 .

Rakotoarivelo, V., J. Sihag, and N. Flamand. 2021. Role of the endocannabinoid system in the adipose tissue with focus on energy metabolism. Cells 10:1279. https://doi.org/10.3390/cells10061279.

Rasmussen, M. S., A. S. Lihn, S. B. Pedersen, J. M. Bruun, M. Rasmussen, and B. Richelsen. 2006. Adiponectin receptors in human adipose tissue: Effects of obesity, weight loss, and fat depots. Obesity (Silver Spring) 14:28-35. https://doi.org/10.1038/oby.2006.5.

Reverchon, M., C. Rame, A. Bunel, W. Chen, P. Froment, and J. Dupont. 2016. VISFATIN (NAMPT) improves in vitro IGF1-induced steroidogenesis and IGF1 receptor signaling through SIRT1 in bovine granulosa cells. Biol. Reprod. 94:54. https://doi.org/10.1095/ biolreprod.115.134650.

Reverchon, M., C. Ramé, J. Cognié, E. Briant, S. Elis, D. Guillaume, and J. Dupont. 2014. Resistin in dairy cows: Plasma concentrations during early lactation, expression and potential role in adipose tissue. PLoS One 9:e93198. https://doi.org/10.1371/journal .pone.0093198.

Reverchon, M., C. Rame, and J. Dupont. 2015. Chemerin: A proinflammatory adipokine involved in the reproduction function? Med. Sci. (Paris) 31:493-498. https://doi.org/10.1051/medsci/ 20153105010.

Revollo, J. R., A. A. Grimm, and S. Imai. 2007. The regulation of nicotinamide adenine dinucleotide biosynthesis by Nampt/PBEF/vis- fatin in mammals. Curr. Opin. Gastroenterol. 23:164-170. https:/ /doi.org/10.1097/MOG.0b013e32801b3c8f.

Rezamand, P., J. S. Watts, K. M. Hunt, B. J. Bradford, L. K. Mamedova, and S. D. Morey. 2012. Bovine hepatic and adipose retinol-binding protein gene expression and relationship with tumor necrosis factor- $\alpha$. J. Dairy Sci. 95:7097-7104. https://doi.org/10 $.3168 /$ jds.2012-5613

Richelsen, B., J. D. Børglum, and S. S. Sørensen. 1992. Biosynthetic capacity and regulatory aspects of prostaglandin E2 formation in adipocytes. Mol. Cell. Endocrinol. 85:73-81. https://doi.org/10 .1016/0303-7207(92)90126-Q.

Rodrigues, R. O., C. Trevisanuto, R. F. Cooke, and J. L. M. Vasconcelos. 2011. Effects of body weight loss on serum progesterone concentrations of non-lactating dairy cows. Theriogenology 75:131-137. https://doi.org/10.1016/j.theriogenology.2010.07.018.

Rodríguez-Carrio, J., N. Salazar, A. Margolles, S. González, M. Gueimonde, C. G. de Los Reyes-Gavilán, and A. Suárez. 2017. Free fatty acids profiles are related to gut microbiota signatures and short-chain fatty acids. Front. Immunol. 8:823. https://doi.org/10 .3389/fimmu.2017.00823.

Rojas, J., M. Chávez, L. Olivar, M. Rojas, J. Morillo, J. Mejías, M. Calvo, and V. Bermúdez. 2014. Polycystic ovary syndrome, insulin resistance, and obesity: Navigating the pathophysiologic labyrinth. Int. J. Reprod. Med. 2014:719050. https://doi.org/10.1155/2014/ 719050.

Romacho, T., M. Elsen, D. Röhrborn, and J. Eckel. 2014. Adipose tissue and its role in organ crosstalk. A. Physiol. 210:733-753. https: //doi.org/10.1111/apha.12246.

Ronti, T., G. Lupattelli, and E. Mannarino. 2006. The endocrine function of adipose tissue: An update. Clin. Endocrinol. (Oxf.) 64:355365. https://doi.org/10.1111/j.1365-2265.2006.02474.x.

Rose, A. J., A. Vegiopoulos, and S. Herzig. 2010. Role of glucocorticoids and the glucocorticoid receptor in metabolism: Insights from genetic manipulation. J. Steroid Biochem. Mol. Biol. 122:10-20. https://doi.org/10.1016/j.jsbmb.2010.02.010.

Rosen, E. D., and B. M. Spiegelman. 2006. Adipocytes as regulators of energy balance and glucose homeostasis. Nature 444:847-853. https://doi.org/10.1038/nature05483.

Rukkwamsuk, T., T. A. Kruip, and T. Wensing. 1999. Relationship between overfeeding and overconditioning in the dry period and the problems of high producing dairy cows during the postparturient period. Vet. Q. 21:71-77. https://doi.org/10.1080/01652176 .1999.9694997.

Sabater, M., J. M. Moreno-Navarrete, F. J. Ortega, G. Pardo, J. Salvador, W. Ricart, G. Frühbeck, and J. M. Fernández-Real. 2010. Circulating pigment epithelium-derived factor levels are associated with insulin resistance and decrease after weight loss. J. Clin. Endocrinol. Metab. 95:4720-4728. https://doi.org/10.1210/jc.2010 -0630 .

Sadri, H., R. M. Bruckmaier, H. R. Rahmani, G. R. Ghorbani, I. Morel, and H. A. van Dorland. 2010. Gene expression of tumour necrosis factor and insulin signalling-related factors in subcutaneous adipose tissue during the dry period and in early lactation in dairy cows. J. Anim. Physiol. Anim. Nutr. (Berl.) 94:e194-e202. https://doi.org/10.1111/j.1439-0396.2010.01005.x.

Sadri, H., M. H. Ghaffari, K. Schuh, C. Koch, and H. Sauerwein. 2021. Muscle metabolome and adipose tissue mRNA expression of lipid metabolism-related genes in over-conditioned dairy cows differing in serum-metabotype. Sci. Rep. 11:11106. https://doi.org/ 10.1038/s41598-021-90577-w.

Sadri, H., M. Mielenz, I. Morel, R. M. Bruckmaier, and H. A. van Dorland. 2011. Plasma leptin and mRNA expression of lipogenesis and lipolysis-related factors in bovine adipose tissue around parturition. J. Anim. Physiol. Anim. Nutr. (Berl.) 95:790-797. https:// doi.org/10.1111/j.1439-0396.2010.01111.x.

Sadri, H., B. Saremi, S. Dänicke, J. Rehage, M. Mielenz, A. Hosseini, and H. Sauerwein. 2018. Lactation-related changes in tissue expression of PEDF in dairy cows. Domest. Anim. Endocrinol. 64:93-101. https://doi.org/10.1016/j.domaniend.2018.04.004.

Sadri, H., J. Winkler, S. Dänicke, J. Rehage, and H. Sauerwein. 2014. Hepatic and adipose mRNA expression of genes related to FGF21 
in response to conjugated linoleic acid (CLA) supplementation in dairy cows during early lactation. J. Dairy Sci. 97:686.

Sánchez-Solana, B., J. Laborda, and V. Baladron. 2012. Mouse resistin modulates adipogenesis and glucose uptake in 3T3-L1 preadipocytes through the ROR1 receptor. Mol. Endocrinol. 26:110-127. https://doi.org/10.1210/me.2011-1027.

Saremi, B., S. Winand, P. Friedrichs, A. Kinoshita, J. Rehage, S. Dänicke, S. Häussler, G. Breves, M. Mielenz, and H. Sauerwein. 2014. Longitudinal profiling of the tissue-specific expression of genes related with insulin sensitivity in dairy cows during lactation focusing on different fat depots. PLoS One 9:e86211. https://doi.org/10 .1371/journal.pone.0086211.

Sauerwein, H., and S. Häußler. 2016. Endogenous and exogenous factors influencing the concentrations of adiponectin in body fluids and tissues in the bovine. Domest. Anim. Endocrinol. 56(Suppl):S33S43. https://doi.org/10.1016/j.domaniend.2015.11.007.

Sauerwein, H., U. Heintges, M. Hennies, T. Selhorst, and A. Daxenberger. 2004. Growth hormone induced alterations of leptin serum concentrations in dairy cows as measured by a novel enzyme immunoassay. Livest. Prod. Sci. 87:189-195. https://doi.org/10 .1016/j.livprodsci.2003.08.001.

Scalia, D., N. Lacetera, U. Bernabucci, K. Demeyere, L. Duchateau, and C. Burvenich. 2006. In vitro effects of nonesterified fatty acids on bovine neutrophils oxidative burst and viability. J. Dairy Sci. 89:147-154. https://doi.org/10.3168/jds.S0022-0302(06)72078-1.

Schiffer, L., L. Barnard, E. S. Baranowski, L. C. Gilligan, A. E. Taylor, W. Arlt, C. H. L. Shackleton, and K.-H. Storbeck. 2019. Human steroid biosynthesis, metabolism and excretion are differentially reflected by serum and urine steroid metabolomes: A comprehensive review. J. Steroid Biochem. Mol. Biol. 194:105439. https://doi .org/10.1016/j.jsbmb.2019.105439.

Schoenberg, K. M., S. L. Giesy, K. J. Harvatine, M. R. Waldron, C. Cheng, A. Kharitonenkov, and Y. R. Boisclair. 2011. Plasma FGF21 is elevated by the intense lipid mobilization of lactation. Endocrinology 152:4652-4661. https://doi.org/10.1210/en.2011 -1425 .

Schuh, K., S. Häussler, H. Sadri, C. Prehn, J. Lintelmann, J. Adamski, C. Koch, D. Frieten, M. H. Ghaffari, G. Dusel, and H. Sauerwein. 2022. Blood and adipose tissue steroid metabolomics and mRNA expression of steroidogenic enzymes in periparturient dairy cows differing in body condition. Sci. Rep. 12:2297. https://doi.org/10 .1038/s41598-022-06014-z.

Schuh, K., H. Sadri, S. Häussler, L. A. Webb, C. Urh, M. Wagner, C. Koch, J. Frahm, S. Dänicke, G. Dusel, and H. Sauerwein. 2019. Comparison of performance and metabolism from late pregnancy to early lactation in dairy cows with elevated v. normal body condition at dry-off. Animal 13:1478-1488. https://doi.org/10.1017/ S1751731118003385.

Schwartz, D. R., and M. A. Lazar. 2011. Human resistin: Found in translation from mouse to man. Trends Endocrinol. Metab. 22:259-265. https://doi.org/10.1016/j.tem.2011.03.005.

Selim, S., T. Kokkonen, J. Taponen, A. Vanhatalo, and K. Elo. 2015. Effect of prepartal ad libitum feeding of grass silage on transcriptional adaptations of the liver and subcutaneous adipose tissue in dairy cows during the periparturient period. J. Dairy Sci. 98:55155528. https://doi.org/10.3168/jds.2014-8986.

Selim, S., S. Salin, J. Taponen, A. Vanhatalo, T. Kokkonen, and K. T. Elo. 2014. Prepartal dietary energy alters transcriptional adaptations of the liver and subcutaneous adipose tissue of dairy cows during the transition period. Physiol. Genomics 46:328-337. https: //doi.org/10.1152/physiolgenomics.00115.2013.

Sethi, J. K., H. Xu, K. T. Uysal, S. M. Wiesbrock, L. Scheja, and G. S. Hotamisligil. 2000. Characterisation of receptor-specific TNFalpha functions in adipocyte cell lines lacking type 1 and 2 TNF receptors. FEBS Lett. 469:77-82. https://doi.org/10.1016/S0014 $-5793(00) 01250-3$.

Shen, L., Y. Zhu, J. Xiao, B. Qian, T. Jiang, J. Deng, G. Peng, S. Yu, S. Cao, Z. Zuo, X. Ma, Z. Zhong, Z. Ren, Y. Wang, Z. Zhou, H. Liu, X. Zong, and Y. Hu. 2020. Relationships between placental adiponectin, leptin, visfatin and resistin and birthweight in cattle. Reprod. Fertil. Dev. 32:402-408. https://doi.org/10.1071/ RD18247.

Simonovic, M., P. G. Gettins, and K. Volz. 2001. Crystal structure of human PEDF, a potent anti-angiogenic and neurite growth-promoting factor. Proc. Natl. Acad. Sci. USA 98:11131-11135. https: //doi.org/10.1073/pnas.211268598.

Singh, S. P., S. Häussler, J. F. L. Heinz, S. H. Akter, B. Saremi, U. Müller, J. Rehage, S. Dänicke, M. Mielenz, and H. Sauerwein. 2014a. Lactation driven dynamics of adiponectin supply from different fat depots to circulation in cows. Domest. Anim. Endocrinol. 47:35-46. https://doi.org/10.1016/j.domaniend.2013.12.001.

Singh, S. P., S. Häussler, J. F. L. Heinz, B. Saremi, B. Mielenz, J. Rehage, S. Dänicke, M. Mielenz, and H. Sauerwein. 2014b. Supplementation with conjugated linoleic acids extends the adiponectin deficit during early lactation in dairy cows. Gen. Comp. Endocrinol. 198:13-21. https://doi.org/10.1016/j.ygcen.2013.12.008.

Song, S. H., K. Fukui, K. Nakajima, T. Kozakai, S. Sasaki, S. G. Roh, and K. Katoh. 2010. Cloning, expression analysis, and regulatory mechanisms of bovine chemerin and chemerin receptor. Domest. Anim. Endocrinol. 39:97-105. https://doi.org/10.1016/j .domaniend.2010.02.007.

Sordillo, L. M. 2016. Nutritional strategies to optimize dairy cattle immunity. J. Dairy Sci. 99:4967-4982. https://doi.org/10.3168/jds .2015-10354

Spoto, B., F. Fezza, G. Parlongo, N. Battista, E. Sgro, V. Gasperi, C. Zoccali, and M. Maccarrone. 2006. Human adipose tissue binds and metabolizes the endocannabinoids anandamide and 2-arachidonoylglycerol. Biochimie 88:1889-1897. https://doi.org/10.1016/ j.biochi.2006.07.019.

Steppan, C. M., S. T. Bailey, S. Bhat, E. J. Brown, R. R. Banerjee, C. M. Wright, H. R. Patel, R. S. Ahima, and M. A. Lazar. 2001. The hormone resistin links obesity to diabetes. Nature 409:307-312. https://doi.org/10.1038/35053000.

Stern, J. H., J. M. Rutkowski, and P. E. Scherer. 2016. Adiponectin, leptin, and fatty acids in the maintenance of metabolic homeostasis through adipose tissue crosstalk. Cell Metab. 23:770-784. https: //doi.org/10.1016/j.cmet.2016.04.011.

Stojanovic, S., M. Deljanin-Ilic, S. Ilic, M. Stefanovic, D. Petrovic, V. Petrovic, and M. Stojanovic. 2020. Adiponectin resistance parameter as a marker for high normal blood pres-sure and hypertension in patients with metabolic syndrome. Hippokratia 24:3-7.

Strieder-Barboza, C., J. de Souza, W. Raphael, A. L. Lock, and G. A. Contreras. 2018. Fetuin-A: A negative acute-phase protein linked to adipose tissue function in periparturient dairy cows. J. Dairy Sci. 101:2602-2616. https://doi.org/10.3168/jds.2017-13644.

Suzuki, Y., Y. H. Hong, S. H. Song, A. Ardiyanti, D. Kato, K. H. So, K. Katoh, and S. G. Roh. 2012a. The regulation of chemerin and CMKLR1 genes expression by TNF-alpha, adiponectin, and chemerin analog in bovine differentiated adipocytes. Asian-Australas. J. Anim. Sci. 25:1316-1321. https://doi.org/10.5713/ajas .2012 .12083

Suzuki, Y., S. H. Song, K. Sato, K. H. So, A. Ardiyanti, S. Kitayama, Y. H. Hong, S. D. Lee, K. C. Choi, A. Hagino, K. Katoh, and S. G. Roh. 2012b. Chemerin analog regulates energy metabolism in sheep. Anim. Sci. J. 83:263-267. https://doi.org/10.1111/j.1740 $-0929.2011 .01002 . x$.

Tanaka, T., M. Narazaki, and T. Kishimoto. 2014. IL-6 in inflammation, immunity, and disease. Cold Spring Harb. Perspect. Biol. 6:a016295. https://doi.org/10.1101/cshperspect.a016295.

Tanasescu, R., and C. S. Constantinescu. 2010. Cannabinoids and the immune system: An overview. Immunobiology 215:588-597. https: //doi.org/10.1016/j.imbio.2009.12.005.

Tang, P., and J. M. Wang. 2018. Chemokines: The past, the present and the future. Cell. Mol. Immunol. 15:295-298. https://doi.org/ 10.1038/cmi.2018.9.

Taylor, E. B. 2021. The complex role of adipokines in obesity, inflammation, and autoimmunity. Clin. Sci. (Lond.) 135:731-752. https: //doi.org/10.1042/CS20200895.

Thorn, S. R., S. Purup, M. Vestergaard, K. Sejrsen, M. J. Meyer, M. E. van Amburgh, and Y. R. Boisclair. 2008. Regulation of mammary 
parenchymal growth by the fat pad in prepubertal dairy heifers: role of inflammation-related proteins. J. Endocrinol. 196:539-546. https://doi.org/10.1677/JOE-07-0501.

Tomlinson, J. W., M. Sherlock, B. Hughes, S. V. Hughes, F. Kilvington, W. Bartlett, R. Courtney, P. Rejto, W. Carley, and P. M. Stewart. 2007. Inhibition of 11b-hydroxysteroid dehydrogenase type 1 activity in vivo limits glucocorticoid exposure to human adipose tissue and decreases lipolysis. J. Clin. Endocrinol. Metab. 92:857-864. https://doi.org/10.1210/jc.2006-2325.

Torabi, R., and H. Ghourchian. 2020. Ultrasensitive nano-aptasensor for monitoring retinol binding protein 4 as a biomarker for diabetes prognosis at early stages. Sci. Rep. 10:594-604. https://doi .org/10.1038/s41598-019-57396-6.

Trayhurn, P., and I. S. Wood. 2004. Adipokines: Inflammation and the pleiotropic role of white adipose tissue. Br. J. Nutr. 92:347-355. https://doi.org/10.1079/BJN20041213.

Trevisi, E., G. Bertoni, R. Lombardelli, and A. Minuti. 2013. Relation of inflammation and liver function with the plasma cortisol response to adrenocorticotropin in early lactating dairy cows. J. Dairy Sci. 96:5712-5722. https://doi.org/10.3168/jds.2012-6375.

Tripathi, D., S. Kant, S. Pandey, and N. Z. Ehtesham. 2020. Resistin in metabolism, inflammation, and disease. FEBS J. 287:31413149. https://doi.org/10.1111/febs.15322.

Tronche, F., C. Kellendonk, H. M. Reichardt, and G. Schütz. 1998. Genetic dissection of glucocorticoid receptor function in mice. Curr. Opin. Genet. Dev. 8:532-538. https://doi.org/10.1016/ S0959-437X(98)80007-5.

Trujillo, M. E., and P. E. Scherer. 2005. Adiponectin - Journey from an adipocyte secretory protein to biomarker of the metabolic syndrome. J. Intern. Med. 257:167-175. https://doi.org/10.1111/j .1365-2796.2004.01426.x.

Tsujioka, T., S. Ito, and A. Ohga. 1992. Female sex steroid residues in the tissues of steers treated with progesterone and oestradiol173. Res. Vet. Sci. 52:105-109. https://doi.org/10.1016/0034 -5288(92)90066-B.

Tsutsumi, C., M. Okuno, L. Tannous, R. Piantedosi, M. Allan, D. S. Goodman, and W. S. Blaner. 1992. Retinoids and retinoid-binding protein expression in rat adipocytes. J. Biol. Chem. 267:18051810. https://doi.org/10.1016/S0021-9258(18)46017-6.

Usui, S., M. Ichimura, S. Ikeda, and M. Okamoto. 2009. Association between serum retinol-binding protein 4 and small dense lowdensity lipoprotein cholesterol levels in young adult women. Clin. Chim. Acta 399:45-48. https://doi.org/10.1016/j.cca.2008.08.017.

Uysal, K. T., S. M. Wiesbrock, M. Marino, and G. S. Hotamisligil. 1997. Protection from obesity-induced insulin resistance in mice lacking TNF-alpha function. Nature 389:610-614. https://doi.org/ $10.1038 / 39335$.

Wang, Y., K. S. L. Lam, L. Chan, K. W. Chan, J. B. B. Lam, M. C. Lam, R. C. L. Hoo, W. W. N. Mak, G. J. S. Cooper, and A. Xu. 2006. Post-translational modifications of the four conserved lysine residues within the collagenous domain of adiponectin are required for the formation of its high molecular weight oligomeric complex. J. Biol. Chem. 281:16391-16400. https://doi.org/10.1074/jbc .M513907200.

Weber, M., L. Locher, K. Huber, Á. Kenéz, J. Rehage, R. Tienken, U. Meyer, S. Dänicke, H. Sauerwein, and M. Mielenz. 2016a. Longitudinal changes in adipose tissue of dairy cows from late pregnancy to lactation. Part 1: The adipokines apelin and resistin and their relationship to receptors linked with lipolysis. J. Dairy Sci. 99:1549-1559. https://doi.org/10.3168/jds.2015-10131.

Weber, M., L. Locher, K. Huber, J. Rehage, R. Tienken, U. Meyer, S. Dänicke, H. Webb, H. Sauerwein, and M. Mielenz. 2016b. Longitudinal changes in adipose tissue of dairy cows from late pregnancy to lactation. Part 2: The SIRT-PPARGC1A axis and its relationship with the adiponectin system. J. Dairy Sci. 99:1560-1570. https://doi.org/10.3168/jds.2015-10132.

Weisberg, S. P., D. McCann, M. Desai, M. Rosenbaum, R. L. Leibel, and A. W. Ferrante Jr.. 2003. Obesity is associated with macrophage accumulation in adipose tissue. J. Clin. Invest. 112:17961808. https://doi.org/10.1172/JCI200319246.

Wellen, K. E., and G. S. Hotamisgil. 2005. Inflammation, stress, and diabetes. J. Clin. Invest. 115:1111-1119. https://doi.org/10.1172/ JCI25102.

Woo, Y. C., C. H. Lee, C. H. Y. Fong, A. Xu, A. W. K. Tso, B. M. Y. Cheung, and K. S. L. Lam. 2017. Serum fibroblast growth factor 21 is a superior biomarker to other adipokines in predicting incident diabetes. Clin. Endocrinol. (Oxf.) 86:37-43. https://doi.org/ 10.1111/cen.13229.

Wu, J., Y. H. Shi, D. M. Niu, H. Q. Li, C. N. Zhang, and J. J. Wang. 2012. Association among retinol-binding protein 4, small dense LDL cholesterol and oxidized LDL levels in dyslipidemia subjects. Clin. Biochem. 45:619-622. https://doi.org/10.1016/j.clinbiochem .2012.02.022.

Xu, S., B. T. Zhu, and A. H. Conney. 2002. Effect of clofibrate administration on the esterification and deesterification of steroid hormones by liver and extrahepatic tissues in rats. Biochem. Pharmacol. 63:985-992. https://doi.org/10.1016/S0006-2952(01)00921-2.

Yamagishi, S.-I., and T. Matsui. 2018. Pigment epithelium-derived factor: A novel therapeutic target for cardiometabolic diseases and related complications. Curr. Med. Chem. 25:1480-1500. https:// doi.org/10.2174/0929867324666170608103140.

Yang, Q., T. E. Graham, N. Mody, F. Preitner, O. D. Peroni, J. M. Zabolotny, K. Kotani, L. Quadro, and B. B. Kahn. 2005. Serum retinol binding protein 4 contributes to insulin resistance in obesity and type 2 diabetes. Nature 436:356-362. https://doi.org/10 .1038 /nature03711.

Zachut, M., G. Kra, U. Moallem, L. Livshitz, Y. Levin, S. Udi, A. Nemirovski, and J. Tam. 2018. Characterization of the endocannabinoid system in subcutaneous adipose tissue in periparturient dairy cows and its association to metabolic profiles. PLoS One 13:e0205996. https://doi.org/10.1371/journal.pone.0205996.

Zhang, L. Q., D. P. Heruth, and S. Q. Ye. 2011. Nicotinamide phosphoribosyltransferase in human diseases. J. Bioanal. Biomed. 3:13-25. https://doi.org/10.4172/1948-593X.1000038.

Zhang, S. X., J. J. Wang, G. Gao, C. Shao, R. Mott, and J. X. Ma. 2006. Pigment epithelium-derived factor (PEDF) is an endogenous antiinflammatory factor. FASEB J. 20:323-325. https://doi.org/ 10.1096/fj.05-4313fje.

Zhou, Y. T., Z. W. Wang, M. Higa, C. B. Newgard, and R. H. Unger. 1999. Reversing adipocyte differentiation: Implications for treatment of obesity. Proc. Natl. Acad. Sci. USA 96:2391-2395. https:/ /doi.org/10.1073/pnas.96.5.2391.

Zieba, D. A., W. Biernat, and J. Barć. 2020. Roles of leptin and resistin in metabolism, reproduction, and leptin resistance. Domest. Anim. Endocrinol. 73:106472. https://doi.org/10.1016/j.domaniend.2020 .106472 . 